Review Article COVID-19 - Special Issue

\title{
Control and prevention of infectious diseases from a One Health perspective
}

Joel Henrique Ellwanger ${ }^{1,2}$, Ana Beatriz Gorini da Veiga ${ }^{3}$ (1), Valéria de Lima Kaminski ${ }^{4}$, Jacqueline María Valverde-Villegas ${ }^{1,5}$, Abner Willian Quintino de Freitas ${ }^{6}$ and José Artur Bogo Chies ${ }^{1,2}$ (1)

${ }^{I}$ Universidade Federal do Rio Grande do Sul - UFRGS, Departamento de Genética, Laboratório de Imunobiologia e Imunogenética, Porto Alegre, RS, Brazil.

${ }^{2}$ Universidade Federal do Rio Grande do Sul - UFRGS, Departamento de Genética, Programa de PósGraduação em Genética e Biologia Molecular - PPGBM, Porto Alegre, RS, Brazil.

${ }^{3}$ Universidade Federal de Ciências da Saúde de Porto Alegre - UFCSPA, Porto Alegre, RS, Brazil.

${ }^{4}$ Universidade Federal de São Paulo - UNIFESP, Instituto de Ciência e Tecnologia - ICT, Laboratório de Imunologia Aplicada, Programa de Pós-Graduação em Biotecnologia, São José dos Campos, SP, Brazil. ${ }^{5}$ Institut de Génétique Moléculaire de Montpellier (IGMM), Centre National de la Recherche Scientifique (CNRS), Laboratoire coopératif IGMM/ABIVAX, UMR 5535, Montpellier, France.

${ }^{6}$ Universidade Federal de Ciências da Saúde de Porto Alegre - UFCSPA, Programa de Pós-Graduação em Tecnologias da Informação e Gestão em Saúde, Porto Alegre, RS, Brazil.

\begin{abstract}
The ongoing COVID-19 pandemic has caught the attention of the global community and rekindled the debate about our ability to prevent and manage outbreaks, epidemics, and pandemics. Many alternatives are suggested to address these urgent issues. Some of them are quite interesting, but with little practical application in the short or medium term. To realistically control infectious diseases, human, animal, and environmental factors need to be considered together, based on the One Health perspective. In this article, we highlight the most effective initiatives for the control and prevention of infectious diseases: vaccination; environmental sanitation; vector control; social programs that encourage a reduction in the population growth; control of urbanization; safe sex stimulation; testing; treatment of sexually and vertically transmitted infections; promotion of personal hygiene practices; food safety and proper nutrition; reduction of the human contact with wildlife and livestock; reduction of social inequalities; infectious disease surveillance; and biodiversity preservation. Subsequently, this article highlights the impacts of human genetics on susceptibility to infections and disease progression, using the SARS-CoV-2 infection as a study model. Finally, actions focused on mitigation of outbreaks and epidemics and the importance of conservation of ecosystems and translational ecology as public health strategies are also discussed.
\end{abstract}

Keywords: Global health, infection, One Health, pathogen, public health.

Received: July 20, 2020; Accepted: December 18, 2020.

\section{Introduction}

Following the emergence of antibiotics and vaccination, many scientists and physicians believed that infectious diseases would cease to be major public health problems, and non-infectious chronic diseases would become more important in terms of public health, a phenomenon known as "epidemiological transition". However, as a result of the emergence of new human pathogens, the re-emergence of many infections, and problems in controlling endemic diseases, infectious diseases remain major public health problems, along with non-infectious chronic diseases (McKeown, 2009; Bedford et al., 2019).

Considering disability-adjusted life years (DALYs) or number of infected individuals, the major infectious diseases on global scale are tuberculosis and other respiratory infections,

Send correspondence to José Artur Bogo Chies. Universidade Federal do Rio Grande do Sul - UFRGS, Departamento de Genética, Laboratório de Imunobiologia e Imunogenética, Av. Bento Gonçalves, 9500, Campus do Vale, CEP: 91501-970, Porto Alegre, RS, Brazil. E-mail: jabchies@ @erra.com.br.
HIV/AIDS and other sexually transmitted diseases, yellow fever, malaria, dengue and other mosquito-borne diseases, viral hepatitis, rabies, cholera, African trypanosomiasis, Chagas disease, leishmaniasis, cysticercosis/taeniasis, dracunculiasis, echinococcosis, cystic echinococcosis, trachoma, foodborne trematodiasis, lymphatic filariasis, onchocerciasis, schistosomiasis, ascariasis, trichuriasis, hookworm disease, Buruli ulcer, leprosy, and yaws (Bhutta et al., 2014; Pigott et al., 2015; GBD 2017 Disease and Injury Incidence and Prevalence Collaborators, 2018; Martins-Melo et al., 2018). Although the impacts of these diseases are global, they affect countries disproportionately, being particularly important on populations living in tropical regions. Most of such diseases can be considered as neglected by governments, research institutions and the pharmaceutical industry, which aggravates the problem of infected individuals and countries where the diseases are endemic.

Urbanization, high population density, deforestation, climate changes, the growing interaction of humans with livestock and wild animals, the increase in the number and frequency of international travels, migratory flows, health 
system failures, social inequalities, and geopolitical conflicts are factors that contribute to the emergence and spread of new pathogens in human populations. As a consequence of the intensity of these factors in different parts of the world, outbreaks of emerging and re-emerging diseases are increasingly common worldwide, being considered "the new normal" in the field of infectious diseases (Bedford et al., 2019; Ellwanger et al., 2020a). In this context, Zika virus infection in the Americas (Faria et al., 2017; Metsky et al., 2017) and Ebola virus infection in Africa (Coltart et al., 2017) became important in terms of public health in the last years. The ongoing Coronavirus Disease 2019 (COVID-19) pandemic (caused by Severe Acute Respiratory Syndrome Coronavirus 2 - SARS-CoV-2) exemplifies how a new human disease can emerge and spread globally in just a few months (Wu $\mathrm{F}$ et al., 2020). Also, the COVID-19 pandemic showed that the capacity of countries to manage public health emergencies is quite heterogeneous, pointing out the need for coordinated and constant actions focused on global health.

Each infectious disease has specific biological and ecological aspects, affecting geographic regions in different ways. Therefore, each disease requires specific control and preventive actions. However, there are effective "universal strategies" to prevent and mitigate infectious diseases in general, with very robust results, especially when such strategies consider human, environmental, animal and pathogen aspects in an integrated way from a One Health perspective (Calistri et al., 2013; Rabinowitz and Conti, 2013; Cunningham et al., 2017). According to this perspective, the intensity and types of interactions between humans, animals and the environment can control the spread of infectious diseases or facilitate the emergence of outbreaks and epidemics (Figure 1). One Healthbased strategies are of high importance, especially in low- and middle-income countries, where infectious diseases are highly prevalent, and resources are limited. These classical initiatives must be part of both the discussion and practical actions of scientists and health professionals worldwide. Increasing efforts to implement and disseminate these actions, as well as to invest in technologies to improve them, is the best strategy for combating infectious diseases in a realistic approach (Ellwanger et al., 2020a; Konda et al., 2020; Mahrous et al., 2020; Morens and Fauci, 2020; Wernli et al., 2020). Thus, this review summarizes the most effective scientific-based initiatives for the control and prevention of infectious diseases aligned with the One Health perspective, in an updated manner.

In the first part of this article, the most effective actions for infectious disease control will be summarized, focused on the maintenance of adequate public health conditions. Subsequently, this article highlights the impacts of human genetics on susceptibility to infections and disease progression. For this purpose, the SARS-CoV-2 infection is used as a study model. Actions focused on mitigation of outbreaks that are useful to deal with public health emergencies are presented. This article also introduces the concept of conservation of ecosystems as a public health strategy. Finally, practical actions to avoid infectious diseases are suggested, considering the concept of translational ecology. This article can be considered a starting point for researchers and decision-makers to evaluate and select evidence-based actions to promote the control and prevention of infectious diseases in communities and research projects, increasing the impact of their actions on society.

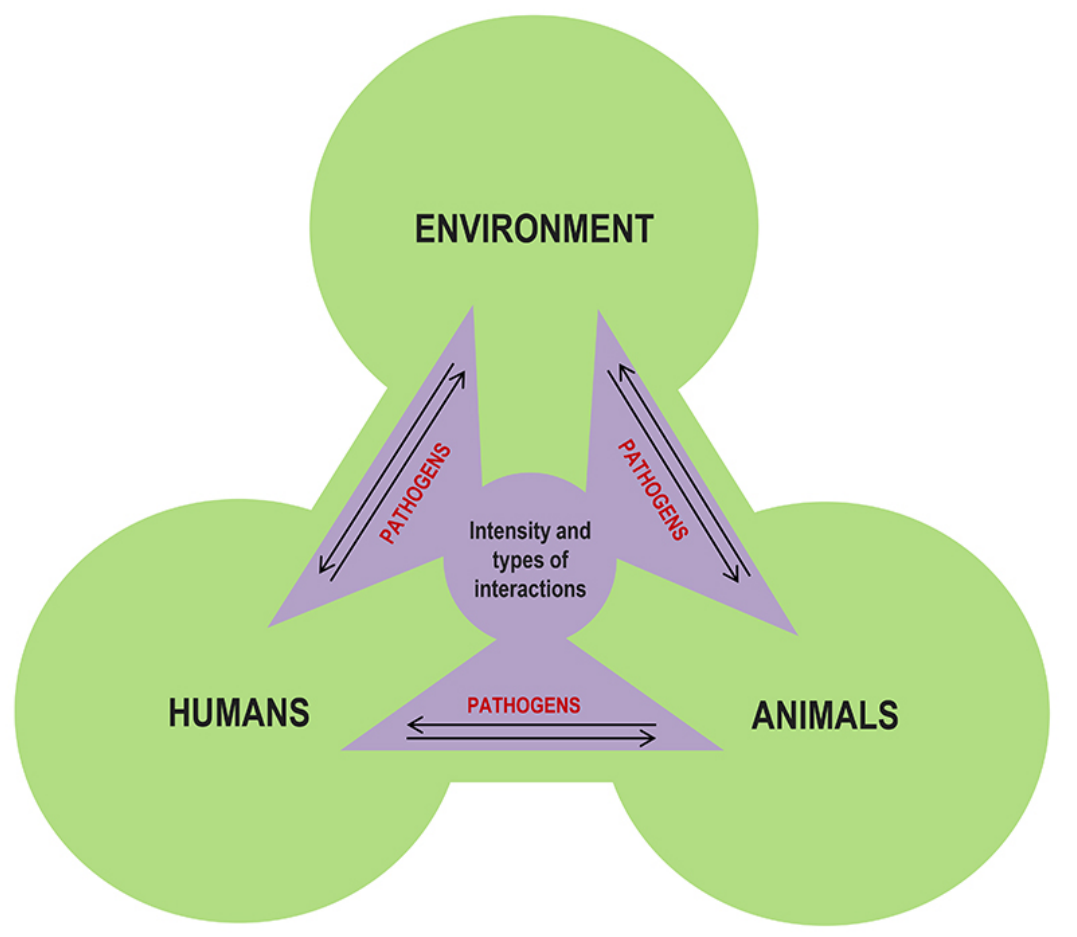

Figure 1 - The One Health perspective. The intensity and types of interactions between humans, animals, and the environment determine the circulation of pathogens between these three actors. Therefore, these interactions can control infectious diseases or facilitate the emergence of outbreaks and epidemics, depending on how humans interact with the environment and other animals. The One Health perspective is used to understand the emergence and spread of infectious diseases and the best ways to control them. Adapted from Ellwanger (2019). 


\section{Actions for control and prevention of infectious diseases: an update}

\section{Vaccination}

In classic terms, vaccines are biological products that induce protective immunity against infections. Vaccines prevent $\sim 2.5$ million deaths each year. Currently, there are vaccines available internationally to prevent 26 infectious diseases. Also, there are other vaccines in the stage of development or already licensed. The positive impact that vaccines had on modern societies is undeniable. The maintenance of the health of human populations living in urban mega-clusters is only possible due to the prevention of infectious diseases spread, a situation also achieved through vaccination (Hodson, 2019; Piot et al., 2019). Data from recent human history clearly show the positive impact of vaccination on our society. After causing about 400 million deaths in the 20th century, smallpox was eradicated in the 1970s after an international vaccination campaign coordinated by the World Health Organization (Nabel, 2013; Meyer et al., 2020). Vaccines also played a fundamental role in the worldwide control of poliomyelitis, diphtheria, Haemophilus influenzae, measles, mumps, pertussis, rubella, and tetanus (Nabel, 2013; Orenstein and Ahmed, 2017).

Vaccines protect not only vaccinated individuals but also the community. Large-scale immunization reduces the exposure of non-vaccinated individuals to pathogens and interrupts or reduces the chain of disease transmission through the process known as "herd immunity", characterized by the presence of numerous individuals immunized against a given pathogen. Also, under this strategy, immunodeficient individuals who cannot receive vaccines are protected. The best vaccines show, simultaneously, a long-lasting effect, cost-effectiveness, and safety, and are easy to administer in the population. All licensed vaccines are safe, once these products were subjected to rigorous safety tests before being made available to the population (Orenstein et al., 2014; Orenstein and Ahmed, 2017; Piot et al., 2019).

Considering the broad benefits of vaccines in preventing infectious diseases, governments need to focus heavily on increasing vaccination coverage by conducting vaccination campaigns and establishing mechanisms to encourage vaccination, such as offering vaccines without cost to the citizens and ensuring easy access to vaccination services (e.g., offering free public transport on vaccination campaign days, or providing mobile vaccination stations to more peripheric communities). Private companies can contribute to vaccination efforts by allowing their employees to take their children to vaccination stations during working hours, without discounting their salaries. Moreover, public-private partnerships with the objective of reducing production costs and improving the distribution of vaccines are essential, especially in developing countries and during epidemic periods (Smith, 2000; Piot et al., 2019; Vouking et al., 2019).

Enabling the large-scale application of vaccines is often a task of high complexity, especially in remote regions of low-income countries. Several vaccines need to be stored and transported under refrigeration, requiring a stable supply of electricity to sustain the "cold-chain", which is not always present in many remote regions. Also, the lack of qualified professionals to administer vaccines associated with the lack of medical supplies hamper vaccination campaigns. Therefore, it is necessary to develop thermostable and easy-to-apply vaccines, as well as to create effective means of transporting vaccines to remote regions (Orenstein et al., 2014; Piot et al., 2019). For example, unmanned aerial vehicles (drones) can be used to deliver vaccines to remote regions, where access by land is difficult (Haidari et al., 2016; Rosser et al., 2018).

Currently, one of the biggest challenges faced in the field of immunization is the anti-vaccine movement. Different society groups aligned with this movement disseminate non-scientific information through the media and internet questioning the safety of vaccines or the need for vaccination, fueling the vaccine hesitancy. These groups, together with the population's lack of access to reliable information on vaccines, contribute to the decline in vaccine confidence (Piot et al., 2019; Gostin et al., 2020). Government efforts must be invested in the dissemination of information regarding the importance and safety of vaccines, clarifying the population's doubts, and reducing the circulations of "fake news" and incorrect information concerning vaccines (Stahl et al., 2016; Succi, 2018). Interestingly, the discussion about vaccines and vaccination coverage gained special attention during the recent SARS-CoV-2 pandemic. A huge number of articles and comments in the mass media both from the most traditional communication industry as well as electronic media, are raising awareness about this question and are pointing to vaccine development and unrestricted access to vaccination as essential steps in the control of this pandemic outbreak, thus rescuing the importance of science in our everyday life.

\section{Testing and diagnosis}

The main infectious diseases currently affecting human populations are likely to be diagnosed through laboratory tests. The testing of infectious diseases and the identification of infected individuals among a specific population are the most critical initiatives for the success of policies focused on the control of infectious diseases. Testing affects the outcome of an infectious disease outbreak, basically, due to the interaction of five factors:

First, testing (in this case, also diagnosis) is the initial step for the treatment of infected individuals. Second, individuals who know they are infected with a particular infectious agent can take measures to avoid its transmission. Third, largescale testing enables the identification of the populations or communities most affected by a given infection, allowing mapping the areas where the problem is most pronounced and directing control and prevention policies more robustly to these target populations and specific locations. Four, virological surveillance trough the identification of viral strains (groups, subtypes, or recombinant strains) estimates recent infections and provides crucial data of viral epidemiology (Lot et al., 2004). Finally, testing plays a crucial role in the surveillance of chronic infectious diseases and controlling outbreaks and epidemics, especially using point-of-care (POC) tests (Mabey et al., 2004; Banoo et al., 2006; Walensky et al., 2007; Kozel and Burnham-Marusich, 2017). 
More investments on POC tests associated with innovation and improvement of diagnostic tests will impact global health, especially in areas and populations with limited resources, where there is insufficient access to laboratories able to perform infectious disease testing (Abou Tayoun et al., 2014). Tuaillon et al. (2020) highlighted the benefits of improving the diagnosis of infections by dried blood spot (DBP) sampling as a tool to increase the access to infectious disease diagnosis worldwide. Along with tests, reagents, consumables, equipment, maintenance, quality control assurance need to be also considered in these investments. Moreover, local manufacturing has to be improved to reach (in the medium and long term) independency from international suppliers. Dependence on a few international suppliers is very problematic, as noted in the current COVID-19 pandemic, in which many countries are having difficulty obtaining the necessary reagents and materials for SARS-CoV-2 testing.

It is important to emphasize that indiscriminately testing the general population may not be the best strategy in terms of surveillance and controlling infectious diseases from a public health perspective (not considering pandemic or epidemic situations, where large-scale testing is required). For example, conducting extensive tests for liver infections in the general population is likely to result in many negative and few positive results, at a high cost. On the other hand, targeting testing programs at individuals with risky behaviors is likely to result in the identification of a higher number of infected individuals at a lower cost (WHO, 2017a). For example, DBS sampling was used for the screening of HIV and hepatitis infections in key populations, such as intravenous drug users (McLeod et al., 2014), sex workers (Shokoohi et al., 2016), homeless people (Foroughi et al., 2017), and men who have sex with men (Bogowicz et al., 2016). In other words, it should be strategically evaluated which populations and areas such testing policies should be targeted more intensively. This direction must be based on risky behaviors and not on "risk groups", avoiding stigmatization of specific portions of the population.

Regarding sexually transmitted infections, diagnostic tests must be offered to any individual who expresses a personal interest in being tested. For example, in Brazil, HIV testing does not need a medical request and is freely available to the population through the Unified Health System (Sistema Unico de Saúde - SUS) (Brasil, 2020). In brief, testing and diagnosis are the initial steps in a series of actions focused on the reduction of problems caused by infectious diseases. Taking the COVID-19 pandemic as an example, it is worth remembering the recent words of the WHO head Tedros Adhanom Ghebreyesus: "Our key message is: test, test, test".

\section{Treatment}

Treatment is the next expected step after an infectious disease is diagnosed. The treatment of infectious diseases has a pivotal effect on the life quality of infected individuals, reducing unwanted impacts of the disease on social and economic aspects, along with the avoidance of possible coinfection-related complications for the patient, such as for those co-infected with HIV and hepatitis C virus (Da Silva et al., 2014; Valverde-Villegas et al., 2017a). The treatment of infections is also essential for controlling certain diseases at the population level. For example, Cohen et al. $(2011,2016)$ showed that HIV-infected individuals under antiretroviral therapy and with undetectable viral load do not transmit the virus through sexual contact. This finding supported the "treatment as prevention" concept, which leads to the global $\mathrm{U}=\mathrm{U}$ (undetectable $=$ uninfectious) campaign (Cohen $e t$ al., 2020). Also, the treatment of HIV-positive women has a very important impact on the reduction of mother-to-children infection, especially in low-income countries where HIV infection rates are high (Nagot et al., 2016). Therefore, treating infections reduces the burden of infectious diseases and, considering HIV infection, prevents new cases of infections.

\section{Development of new antimicrobial drugs}

Antimicrobial drugs are one of the main tools that humanity has to treat numerous infectious diseases and includes antibiotics, antivirals, antifungals, and antiparasitic agents. Among antimicrobial drugs, antibiotics have a prominent role due to their extensive use worldwide and the variety of therapeutic classes (e.g., $\beta$-Lactams, Tetracyclines, Rifamycins, Macrolides, Streptogramins, Quinolones), being used to treat several bacterial diseases, such as tuberculosis, gonorrhea, and leprosy. Humanity has benefited dramatically from the use of antibiotics, which have reduced both morbidity and mortality from bacterial infections. However, the indiscriminate and often inappropriate use of antibiotics in humans and other animals associated with the disposal of these drugs in the ecosystems has resulted in the selection of multi-resistant microorganisms. Antimicrobial resistance is currently one of the biggest problems in the field of infectious diseases. There is an urgent need to develop new antimicrobial drugs to be used in the treatment of infections by multidrug-resistant strains (Bronzwaer et al., 2002; Coates et al., 2002; Tenover, 2006; Morgan et al., 2011; Piddock, 2012; Marston et al., 2016). The benefits offered to human populations through the use of antimicrobial drugs are enormous and should not be overlooked by governments, research institutions, and the pharmaceutical industry. Although the development of new antimicrobial drugs is crucial for continued control of infectious diseases worldwide, the wide range of antimicrobial agents already available is an asset in the hands of researchers and the medical staff, enabling drug repurposing strategies. Nevertheless, the COVID-19 pandemic is teaching us that this resource should be used with extreme caution. Antimicrobials traditionally used to treat specific infections can be either effective or even deleterious when targeting new infectious agents in different contexts (Kandeel et al., 2020; Mallhi et al., 2020; Martinez, 2020; Senanayake, 2020).

\section{Reduction of contact with wildlife and livestock}

Between $58-75 \%$ of infectious diseases that affect humans are originated from microorganisms hosted in non-human animals. In other words, the majority of human infectious diseases have a zoonotic origin (Taylor et al., 2001; Woolhouse and Gowtage-Sequeria, 2005; Jones et al., 2008; Ellwanger et al., 2020a). The intense and close contact with wild animals creates opportunities for the emergence of new infectious diseases in humans since it allows the insertion of new pathogens in the human population (Wolfe et al., 2005; Nava et al., 2017). The transposition of pathogens 
between species is a complex process called zoonotic spillover. Such process depends on ecological factors and genetic characteristics of the hosts (humans and other species, including domestic and wild animals) and pathogens. The frequency and intensity of the contact between humans and other animals increase the chance of spillover events between these species and the emergence of new infectious diseases in humans. If the pathogen that was introduced into the human population is faced with favorable conditions for its replication and spreading, outbreaks or epidemics may occur (Morse, 1995; Plowright et al., 2017; Ellwanger and Chies, 2018a).

The handling and consumption of meat, blood, and offal from wild animals (bushmeat/wildmeat) are very common in different regions worldwide, mainly in Asia and Africa, although in other regions of the world the bushmeat consumption is also very intense, as in Brazil (Mendonça et al., 2016; Ripple et al., 2016; Ordaz-Németh et al., 2017). It is well known that this practice has facilitated the introduction of different pathogens in the human population, including HIV (Gao et al., 1999; Hahn et al., 2000).

The Severe Acute Respiratory Syndrome Coronavirus (SARS-CoV) emerged in China in 2002-2003, and the Middle East Respiratory Syndrome Coronavirus (MERS$\mathrm{CoV}$ ) emerged in the Middle East in 2012, both as a result of the close interaction of humans with animals (Kock et al., 2020). Bats are the natural hosts of SARS-CoV and MERS$\mathrm{CoV}$, whereas palm civets were the intermediate host for SARS-CoV, and camels were the intermediate host for MERSCoV (Salata et al., 2019; Xu, 2020). Again, it is very likely that the bushmeat trade contributed to the emergence of the recent human SARS-CoV-2 (COVID-19) pandemic (Li J et al., 2020). Bats (Zhou P et al., 2020) and pangolins (Manis javanica) (Lam et al., 2020; Zhang et al., 2020) host SARS$\mathrm{CoV}$-2-related coronaviruses. Hence, it is believed that bats probably served as natural reservoirs hosts of the virus and another species (pangolins or another animal species not yet identified) potentially served as an intermediate host, in which the virus may have evolved, ultimately acquiring characteristics that allowed this pathogen to infect humans and spread among the human population. However, the actual roles of these animal species in the emergence of SARS-CoV-2 are still under debate (Zhang and Holmes, 2020). In this context, the role of recombination of viruses from different species (bat and pangolin) in the emergence of the human SARS-CoV-2 is a possibility already suggested (Li X et al., 2020). However, this aspect is still controversial and remains a matter of investigation (Boni et al., 2020).

Considering the plethora of pathogens in wild animals and the intense interaction of humans with these animals, spillover events resulting in outbreaks and epidemics will repeatedly happen in human history. Thus, the way to reduce these events is to limit the interaction of humans with wild animals, mainly with mammals and birds (known as critical sources of zoonotic diseases). A compelling and cost-effective way to achieve this goal is to limit the wildlife trade and wildlife-derived products, especially in countries where bushmeat consumption endangers wild species (Kock et al., 2020; Li J et al., 2020; Zhang and Holmes, 2020).
Besides bushmeat, the trade of exotic animals to be used as pets also narrows the barriers between humans and exotic pathogens. Thus, the trade of exotic animals must be combated intensely. In addition, it is essential to make exotic pet owners and professionals who work in direct contact with animals (e.g., biologists, veterinarians, animal keepers) aware of the risks related to zoonosis and emerging diseases, potentially minimizing the risks of infections and spillover events (Chomel et al., 2007; Rabinowitz and Conti, 2013).

Revisiting the Nipah virus and avian influenza (H5N1 virus) cases, Morse et al. (2012) discuss the apparent opposing forces of economic development and public health. As conciliation alternatives, the authors proposed the creation of financial incentives for industries to reduce their environmental impacts, more secure food supply chains as an alternative to bushmeat trade, as well as more intensive surveillance of livestock in boundary areas with intense human-animal contact (Morse et al., 2012).

Human contact with livestock animals also facilitates the emergence of new human diseases, since numerous animals (and their pathogens) come into contact daily with humans whose work involves handling these animals. Of note, swine are prone to infection by avian and human influenza viruses, which allows the mixing of genetic information from different, but closely related, viral species (a phenomenon called genetic reassortment). This process facilitates the generation of new viral strains, including pandemic influenza viruses. As a consequence of this process, swine are considered "mixing vessels" for influenza viruses (Castrucci et al., 1993; Zhou et al., 1999; Brown, 2001; Ma et al., 2009).

In brief, new human infectious diseases are usually caused by pathogens that originally circulated only in wild animals and, after a spillover event, also infect and trigger diseases in humans (Taylor et al., 2001; Jones et al., 2008). These precepts are valid and easy to understand. However, allegations that wild animals, especially exotic species, are the causative agents of the emergence of new human diseases are common and incorrect. Non-human animals are actually the source of new human pathogens, but not the cause of the emergence of new diseases. The factors involved in the "jump" of pathogens from non-human animals to humans are generally associated with cultural and economic human practices, such as animal confinement for meat production, hunting, and deforestation. These practices intensify human contact with several animal species and with the wide range of pathogens hosted in such species, facilitating spillover events (Daszak et al., 2000; Wolfe et al., 2005; Espinosa et al., 2020).

Taken together, reducing and controlling human contact with wild species and livestock animals is an important initiative to minimize the chances of the emergence of new infectious diseases in the human population. In this context, the requirement to comply with strict sanitary rules for meat trading needs to be extended to all meat trading locations, including popular and traditional markets (Daszak et al., 2020; Dobson et al., 2020). The probable link between the emergence of SARS-CoV-2 and a wet market in Wuhan city (Hubei province, central China) (Whitworth, 2020) clearly demonstrates the needs for the actions mentioned above. 


\section{Biodiversity preservation and containment of climate change}

The behavior and interactions of humans and non-human animals alter the abundance, diversity, and distribution of microorganisms in the environment. Similarly, microorganisms alter the behavior, distribution, and abundance of animal species, prey-predator interactions, and many other aspects of the ecosystems. Consequently, these interactions affect the ecology of pathogens and infectious diseases. Of note, diverse ecosystems are more resilient to changes and insults than more homogeneous environments. Thus, the preservation of biodiversity is associated with reduced changes in the ecology of hosts and their pathogens and, therefore, with a lower risk of infectious diseases emergence (Mills, 2006; Keesing et al., 2010; French and Holmes, 2020; Gibb et al., 2020; Mendoza et al., 2020). Moreover, deforestation, mining, intensive land use, and other activities associated with the degradation of ecosystems, in connection with the previous topic approached in the present review, increase the interaction of humans with different wild species, facilitating spillover events. These activities also increase human exposure to vectors of different diseases, such as mosquitoes (Ellwanger et al., 2020a).

Forests play a crucial role in regulating the global climate. The loss of vegetation cover is associated with higher levels of greenhouse gas emissions in the atmosphere (e.g., carbon dioxide), loss of water cycle regulation, and other environmental disturbances, fueling the rise in global average temperature and climate changes (Shukla et al., 1990; Bonan, 2008; Fearnside, 2008; Nogueira et al., 2018; West et al., 2019). Host-pathogen interactions and vector dynamics are affected by many abiotic factors, such as wind and rain patterns and changes in temperature. Therefore, climate changes and extreme weather events are important determinants of the emergence and spread of infectious diseases. Extreme climatic events, such as heavy rains, hurricanes and floods, facilitate the proliferation of disease vectors and are associated with the increase in cases of diseases such as gastroenteritis, leptospirosis, and cholera. Besides that, higher temperatures and extreme weather events facilitate fires in forest environments, contributing to habitat loss and threatening several species (Wu et al., 2016; Ellwanger and Chies, 2018b; Khan et al., 2019; French and Holmes, 2020).

Deforestation, biodiversity loss and climate change are highly connected and give rise to a vicious circle, favoring the spread of infectious diseases through many mechanisms. The frequency and intensity of outbreaks and epidemics tend to increase as climate changes become more intense. For these reasons, biodiversity preservation and reduction of climate change must receive special attention on the agenda focused on the control and prevention of infectious diseases (Ellwanger et al., 2020a).

\section{Vector control}

Animal vectors transmit over $17 \%$ of all infectious diseases in the world. Vector-borne diseases affect an enormous number of individuals worldwide in terms of morbidity and mortality, causing 700,000 deaths each year. Vector-borne diseases are caused by viruses (e.g., Dengue virus, Zika virus), bacteria (e.g., Rickettsial diseases, typhus), and parasites (e.g., lymphatic filariasis, malaria, schistosomiasis). Mosquitoes of the genus Aedes, Anopheles and Culex, along with ticks, triatomine bugs, aquatic snails, lice, fleas, tsetse flies, blackflies, and sandflies are the most relevant disease vectors. Mosquitoes alone are responsible for the transmission of various diseases, including chikungunya, dengue, lymphatic filariasis, yellow fever, Zika, Rift Valley fever, malaria, Japanese encephalitis, and West Nile fever. Of note, mosquitoes are amongst the animals that cause the highest rates of morbidity and mortality in the world (WHO, 2020a, b).

The control of vector-borne diseases is a fundamental action to reduce the global burden of infectious diseases. Vector control actions must be implemented at the local level but must be coordinated globally. According to the World Health Organization, effective vector control should include poverty reduction, promotion of good health and well-being, access to clean water and sanitation, development of sustainable cities and communities, climate actions, and partnerships between nations to promote global health (WHO, 2017b). Specifically, vector control involves a series of strategies that must be implemented according to the needs of each location, country and epidemiological particularities, which may involve the use of insecticides, predator species, habitat manipulation, house improvement, the release of genetically modified mosquitoes in the environment, among other strategies (Flores and O'Neill, 2018; Wilson et al., 2020). Vector control is an investment that brings economic returns due to the prevention of numerous infectious disease cases, saving the lives of thousands of people and preventing consequential economic losses (Alonso et al., 2017).

\section{Environmental sanitation}

Adequate conditions of environmental (basic) sanitation are determinants of population health and include mainly the access to treated water, garbage collection, and sewage system and treatment. Along with vaccination, environmental sanitation is the factor that most contributed to the promotion of public health in the last century (Institute of Medicine, 1988; Nabel, 2013; Hodson, 2019). However, 2.5 billion people in the world still do not have access to adequate sanitation conditions. Several diseases are associated with inadequate sanitation facilities and lack of access to treated water and sewage treatment, especially parasitic and viral enteric diseases (Mara et al., 2010; Adane et al., 2017; Freeman et al., 2017). For instance, inadequate conditions of sanitation and poor hygiene practices are strongly associated with a higher incidence of childhood diarrhea in Brazil (Heller et al., 2003; Bühler et al., 2014); strikingly, it is estimated that 2,195 children die daily of diarrhea in the world, and $88 \%$ of these deaths are due to unsafe water, poor sanitation systems and insufficient hygiene (CDC, 2017).

In addition to diseases transmitted by contaminated water, the lack of sanitation facilitates the proliferation of mosquitoes that spread numerous viral species (e.g., Dengue virus, Zika virus, West Nile virus). Accordingly, poor water supply services lead people to store water in containers, whereas the lack of adequate sewage systems gives rise to open sewers; these factors prove breeding sites for mosquitoes, contributing to an increase in vector-borne diseases (Degroote et al., 2018). The proliferation of other urban pests that can 
transmit various pathogens to humans, such as rodents, is also favored by inadequate sanitation services (Moreira et al., 2013; Rahelinirina et al., 2019; Murray et al., 2020). The diseases associated with the lack of sanitation also cause severe economic damages to the affected families and to the economy of the countries, since these diseases cause significant losses in working days and huge expenses with the treatment of the affected individuals, among other related issues (Van Minh and Hung, 2011; Fuente et al., 2020).

Of note, the lack of environmental sanitation is associated with $10 \%$ of the global human disease burden (Mara et al., 2010). For these reasons, investments in sanitation could minimize numerous public health problems and bring robust economic gains (Hutton et al., 2007; Van Minh and Hung, 2011; Prüss-Ustün et al., 2017). Environmental sanitation is, therefore, one of the most effective and robust factors for the control and prevention of infectious diseases.

\section{Infectious disease surveillance}

Surveillance is one of the most effective strategies for the control of infectious disease outbreaks and containment of emerging pathogens. Robust epidemiological surveillance systems allow the monitoring of the circulation of pathogens in humans, non-human animals, and human-animal interfaces, facilitating the early detection of emerging diseases with potential of causing epidemics and pandemics. Also, epidemiological surveillance is the mechanism that allows detecting sudden increases in cases of a particular disease. Currently, genome-based technologies are used in the rapid and highly accurate diagnosis and surveillance of infections. These technologies also allow the monitoring of outbreaks, epidemics, and pandemics accurately and practically in real time (Ellwanger et al., 2017; Geoghegan and Holmes, 2017; Grady and Loman, 2018; Holmes et al., 2018; Ellwanger et al., 2019).

Classic or genome-based surveillance strategies must focus on populations most susceptible to infectious diseases. It is also necessary to give importance to the risks associated with emerging pathogens, prioritizing those with high public health relevance (e.g., high transmissibility among humans, high mortality). In addition, an adequate surveillance system must prioritize partnerships between research institutions and public health agencies, focusing on long-term investments, where the training of technical personnel, diagnostic capacity, and rapid responses to outbreaks occurs in an integrated, systemic and lasting manner. Professionals involved in research activities in outbreak situations must be committed to building (or improving) solid diagnostic, healthcare, and surveillance systems at the location where the outbreak occurred. This approach will enable research activities and, in a complementary way, assist in controlling future outbreaks with the help of trained local scientists and health professionals (Heymann et al., 2016; Yozwiak et al., 2016; Yamey et al., 2017; Holmes et al., 2018; Ellwanger et al., 2019).

Pathogens and epidemics do not respect national borders or political and cultural barriers. Flaws in the surveillance systems can make infectious disease outbreaks become global emergencies. Therefore, actions focused on the control of infectious diseases require health diplomacy and respect for global and local ethical issues, which depend on robust international partnerships and cooperation between global leaders (Bedford et al., 2019). The COVID-19 pandemic illustrates the importance of both the epidemiological surveillance and the quick response to the identification and control of a new potential pandemic pathogen. In this context, the evaluation of outcomes and consequences, comparing the different measures taken by different countries around the world during the COVID-19 pandemic, will help us to establish (and learn) which approaches have given better results in such a situation. Nevertheless, independently of the approaches and measures taken, it is quite appropriate to say that epidemiological surveillance is one of the most critical initiatives for the control of infectious diseases.

\section{Urban planning (control of human agglomeration and adequate urbanization)}

Historically, epidemics have arisen in human populations since the establishment of the first urban settlements. In other words, epidemics appear in human history along with the first villages and cities. Human agglomeration is an essential factor for human-to-human transmission of infectious diseases. This kind of transmission sustains outbreaks and epidemics of non-vector borne infections. In brief, the concentration of people in cities promotes the ideal conditions for the spread of diseases transmitted by direct contact (Wolfe et al., 2007; Bañuls et al., 2013).

Human agglomeration, unplanned urbanization and deurbanization (neglected/abandoned urban areas) facilitate the emergence and spread of infectious diseases since these factors are associated with sustained human-to-human transmission of pathogens, lack of sanitation, closer contact with wildlife, garbage accumulation, and proliferation of disease vectors (Gubler, 2011; Neiderud, 2015; Herfst et al., 2017; Dalziel et al., 2018; Eskew and Olival, 2018; Tian et al., 2018). Therefore, urban planning that prioritizes the population access to health infrastructure is a meaningful way to control infectious diseases, since it creates the conditions necessary for life in cities to be healthy, avoiding human settlements in environments without adequate sanitary conditions. For this objective to be achieved, it is crucial that architects, environmental and sanitary engineers, and urban planners actively participate in discussions involving the role of urban factors in the spread of infectious diseases, bringing solutions to mitigate these problems (Corburn, 2015; Giles-Corti et al., 2016). In this context, it is important to keep in mind that not only the population size, but also human mobility patterns can contribute to the spread of infectious diseases. Taking the COVID-19 pandemic as an example, the rapid virus spread around the world was followed by different approaches aiming to mitigate or reduce its propagation, including non-pharmaceutical interventions, such as human mobility restrictions, school closures, and the establishment of social distancing measures. Of note, non-pharmaceutical interventions have significantly reduced the spread of the virus in several countries (Candido et al., 2020; Flaxman et al., 2020; Lai et al., 2020; Pan et al., 2020). We are now observing the figures and patterns of the different epidemic waves that are propagating from big to small cities, and from 
one country to another. Certainly, we will have much to learn about viral spread patterns in the next years by assessing, and questioning, the decisions taken during the period of this pandemic, and its consequences.

\section{Social actions to promote the reduction of population growth}

The world population is close to 8 billion individuals and, currently, the number of people living in cities is higher than that of people living in rural regions (Buhaug and Urdal, 2013; Jensen and Creinin, 2020). The increase in the global human population causes a series of social, health, and environmental concerns. High birth rates in families with social and economic vulnerabilities are associated with poverty and lack of access to formal education, creating a vicious circle of social problems. Also, the growing demand for natural resources to meet human consumption requirements causes environmental degradation, leading to the collapse of ecosystems and reduction of biodiversity (Vörösmarty et al., 2000; Allen, 2007; Crist et al., 2017; Gomes da Silva and Gouveia, 2020). Overpopulation, poverty, high demand for food and consumer goods, large-scale agricultural practices and industrial production, and environmental degradation act synergistically, facilitating the emergence of new pathogens among human populations. The spread of known infectious diseases is also facilitated in overpopulated regions.

Therefore, overpopulation and its interconnected factors must be controlled as an additional way to prevent and contain the spread of infectious diseases. This action should be applied through poverty reduction, access to birth control advice and methods, and gender equality. These goals require investment in the promotion of formal education and improvements in access to contraceptive methods (Allen, 2007; Crist et al., 2017; Jensen and Creinin, 2020). As a classical example, women's educational attainment is the main factor involved in both the reduction of birth rates and delayed childbearing. Better knowledge regarding the use of contraceptives and more efficient access to these methods has contributed to the observed low fertility in higher social strata worldwide (Kravdal, 1992; Mathews and Ventura, 1997).

Taking together, promoting social actions focused on the reduction of population growth is an additional way to control the spread of infectious diseases. However, it is important to highlight that mandatory governmental measures of birth control should be emphatically avoided.

\section{Sex education and promotion of safe sex}

The promotion of safe sex is an essential initiative for the prevention of sexually transmitted infections and encompasses a series of joint actions, including campaigns focused on the prevention of these infections, the distribution of male and female condoms, promotion of sexual health through medical assistance, and school-based sexual education. In terms of public health, these actions have beneficial effects on the reduction of sexually transmitted infection rates. For these actions to be applied effectively, they must be demystified, viewed without prejudice or religious bias, being properly discussed and expanded, focusing on adolescents, adults, and the elderly of all sexual orientations (Mullinax et al., 2017; Ford et al., 2017).
In addition to the classic initiatives of promotion of safe sex, other innovative strategies with the same purpose should be encouraged, such as the Pre-Exposure Prophylaxis (PrEP), focused on the prevention of HIV infection (CDC, 2019). PrEP consists of taking anti-HIV drugs by uninfected individuals to prevent HIV infection in the case of exposure to the virus. Robust evidence indicates that PrEP is safe and highly effective, virtually eliminating the risk of infection if appropriately taken (Grant et al., 2010; Fonner et al., 2016; McCormack et al., 2016). It should be offered mainly to individuals with risky behavior or with a history of repeated potential exposure to HIV. Together, sexual education and the various available forms of promoting safe sex have a significant impact on reducing the rates of sexually transmitted infections.

\section{Promotion of hygiene practices}

In 1878, Louis Pasteur established that germs were causative agents of infectious diseases. After the "Germ Theory of Diseases" was accepted, it became evident that personal and familial hygiene practices were effective in reducing the occurrence of infections. The connection between hygiene practices (e.g., hand hygiene, use of soap, adequate waste disposal, hygiene education) as an effective way to avoid infections and reduce human mortality had been supported by robust and multiple evidence (Greene, 2001; Larson and Aiello, 2001; Aiello and Larson, 2002; Casanova and Abel, 2013).

Although the pivotal role of personal hygiene practices as a strategy to prevent diseases is well established in highincome countries, this is still not the reality for many lowincome nations due to the lack of knowledge or scarcity of structure for the distribution of treated water, sewage collection, and appropriate kitchens and bathrooms. To reduce the diseases associated with the lack of personal hygiene, governments need to ensure adequate housing conditions for the population, with proper sanitary installations, in addition to investing in education on how to prevent diseases linked to poor hygiene. In high-income countries, simple hygiene practices should be reinforced, such as hand washing after touching or manipulating structures for public use. These simple measures are of crucial importance to contain the spread of viral infections, especially in the months of seasonal pathogens' circulation (Inaida et al., 2016; WHO, 2020c).

\section{Access to food, food security and proper nutrition}

The nutritional status significantly influences the susceptibility and pathogenesis of infectious diseases in several ways. For example, protein deficiency and malnutrition increase the susceptibility to infections, and facilitate the pathogenesis of diseases, including HIV infection, malaria, and tuberculosis (Cegielski and McMurray, 2004; Schaible and Kaufmann, 2007; Katona and Katona-Apte, 2008; Ibrahim et al., 2017).

Recently, maternal protein deficiency was associated with increased susceptibility to congenital Zika syndrome, a condition characterized by developmental impairment in the fetus and caused by maternal Zika virus infection (BarbeitoAndrés et al., 2020). This finding exemplifies how nutritional status can act as an important cofactor in the outcome of viral infections. Also, deficiency of micronutrients (e.g., vitamin A, selenium, iron) has critical impacts on immune responses 
to infectious diseases. For example, zinc deficiency was associated with increased morbidity of several infections, including malaria and respiratory infections, especially in children (Bahl et al., 1998; Bhaskaram, 2002; Walker and Black, 2004; Ellwanger et al., 2011). These examples indicate that proper nutrition is a public health issue that also reverberates on the prevention of infectious diseases.

Adequate eating habits depend on access to information and are influenced by cultural habits. However, these factors are just a few of the many determinants of proper nutrition. Importantly, proper nutrition is highly dependent on food security, which means not only access to food with guaranteed nutritional and microbiological quality: food security means that individuals and families would have enough income to acquire these foods sufficiently, in an accessible, constant and sustainable way (Schmidhuber and Tubiello, 2007; Glamann et al., 2017). Many populations depend on bushmeat consumption to obtain sufficient intake of protein, which results in risks for the emergence of new human infectious diseases. Therefore, the promotion of food security is essential to prevent vulnerable populations depend on bushmeat as a source of protein. In other words, food security plays a very important role in reducing human contact with potential new pathogens from meat and biofluids of wild animals (Friant et al., 2020). However, besides increasing food security and proper nutrition it is necessary to promote and maintain sustainability in agricultural practices (Sayer and Cassman, 2013). Innovative agricultural technologies and policies are needed to face environmental problems. For example, regenerative agriculture, permaculture and other sustainable agricultural practices must be developed and expanded, reducing energy demands and decreasing the environmental impacts of the food production chain (Rhodes, 2012; Akhtar et al., 2016). Moreover, livestock production must meet animal hygiene and sanitation measures in order to guarantee not only animal health, but also food supply, food security and human health (Bianchini et al., 2019).

Food security, agricultural practices, environmental issues, and proper nutrition are connected and have important long- and short-term impacts on the environment, public health and the control and prevention of infectious diseases. Therefore, governments have a responsibility to guarantee these fundamental rights to their citizens.

\section{Reduction of social inequalities}

Social inequality is one of the main drivers of poor population health. Individuals with insufficient income are incapable of having proper daily diets, invest in education and professional training, and have adequate leisure activities as a way to promote physical health and reduce stress, being, therefore, more susceptible to several diseases. Of note, access to health services is essential for the diagnosis, treatment, and prevention of diseases. In an environment of social inequality, wealthier individuals have better access to these services. In contrast, most impoverished populations face many difficulties in accessing health services because they generally live far from the places where these services are offered and also have less access to means of transport. Other factors aggravate this scenario, such as the lack of formal education commonly observed in the poorest individuals, making it difficult for this portion of the population to get medical assistance (Farmer, 1996; Quinn and Kumar, 2014).

Social inequalities and poverty have a direct and very palpable impact on infectious diseases. For example, the spread of the tuberculosis bacillus (Mycobacterium tuberculosis) is facilitated in poorly ventilated spaces and inadequate housing, factors commonly observed in the homes of the low-income populations, in which many people live together in small spaces (Lönnroth et al., 2009; Lönnroth et al., 2010; Lygizos et al., 2013). Moreover, people in poverty live in homes often without access to safe water and other adequate conditions of environmental sanitation, allowing the occurrence of different enteric diseases, soil-transmitted helminth infections, Leishmaniasis, among other diseases (Cifuentes and Rodriguez, 2005; Hotez et al., 2005; Alvar et al., 2006; Echazú et al., 2015). Low income, poor education, unemployment, discrimination, violence, and other povertyrelated problems are associated with increased HIV infection burden and poor access to antiretroviral therapy (ILOAIDS, 2005; Kalichman et al., 2006; Haacker and Birungi, 2018; Leddy et al., 2019). Poor people are also more susceptible to the COVID-19 pandemic, as they live in conditions more prone to the spread of the SARS-CoV-2, in addition to being more susceptible to mortality due to this infection (Ahmed et al., 2020). Taking together, the reduction of social inequalities is a robust form of prevention and control of infections at the population level.

\section{Impacts of host genetics on susceptibility to infections and disease progression: SARS- CoV-2 as a study model}

\section{The role of host genetic on infectious diseases}

Researchers have learned that when individuals are exposed to pathogens, some of them will be infected (normal or higher susceptibility to infection) whereas others will not be infected (reduced susceptibility or resistance to infection). Also, a remarkable feature observed in most infectious diseases is inter-individual phenotypic variability, with infected individuals presenting clinical features ranging from asymptomatic infection to fatal outcome during clinical progression. In many diseases, this clinical variability depends on immune responses against pathogens, which are influenced by host genetic factors (Mozzi et al., 2018; Casanova and Abel, 2020).

Several infectious diseases follow a complex mode of inheritance, with multiple genetic and environmental factors contributing to susceptibility. Also, genetic variants have distinct effects on the phenotype, with major or modest effect (Stringer et al., 2011). Classical examples of major contributor effects were found in malaria, in which natural erythrocyte polymorphisms are protective against severe malaria (Ruwende et al., 1995; Allen et al., 1997; Egan, 2018). Also, homozygous individuals for the 32 base-pair deletion in the CCR5 gene (CCR5 $\Delta 32)$ are highly resistant to HIV infection (Ellwanger et al., 2020b).

Human leukocyte antigen (HLA) alleles are the prototypical candidates for genetic susceptibility to infectious 
diseases since HLA molecules are responsible for presenting viral antigens to $\mathrm{CD}^{+}$and $\mathrm{CD}^{+} \mathrm{T}$ cells (Horton et al., 2008). HIV, hepatitis $\mathrm{C}$ and $\mathrm{B}$, leprosy, tuberculosis, leishmaniasis, helminthiasis, dengue and influenza are some examples of infections for which susceptibility or disease progression are influenced by specific HLA alleles (Blackwell et al., 2009).

As examples of HLA alleles associated to susceptibility and disease progression, HLA-B*27 and HLA-B*57 alleles were associated to slower progression to AIDS, control of viral load and high frequencies of $\mathrm{CD} 4^{+} \mathrm{T}$ cells (Migueles $e t$ al., 2000; Chopera et al., 2008); conversely, the HLA-B*35 allele was associated with rapid disease progression to AIDS (Tomiyama et al., 1997). The HLA-A*11, HLA-B*35 and HLA-DRB $1 * 10$ alleles were associated with susceptibility to influenza H1N1 infection (Dutta et al., 2018). The HLA-A*02:07 and HLA-B*51 alleles were associated with increased secondary severe disease caused by Dengue virus (Stephens et al., 2002). Also, the HLA-DRB1*1202 allele was associated with susceptibility to SARS-CoV (Keicho et al., 2009), and in contrast, HLA-Cw1502 and HLA-DR0301 alleles were associated with resistance against SARS-CoV (Wang et al., 2011).

Our research group has already made several contributions regarding the role of host genetics on infectious diseases. For example, we have already investigated the impact of polymorphisms of the TLR-9, HLA-G and CCR5 genes on viral hepatitis (Da Silva et al., 2014; Valverde-Villegas et al., 2017a; Ellwanger et al., 2020c). These studies helped to understand, for example, which populations have differences in susceptibility to these infections. Also, the immune response to infections is influenced by interactions between different loci. Therefore, studies addressing epistatic interactions contribute to the understanding of the role of host genetic on infectious diseases. For example, some HLA alleles in combination with other gene variants were associated with delayed progression to AIDS (Magierowska et al., 1999; Martin et al., 2002), and a CXCL10 rs56061981 and CCL22 rs4359426 combination predicted susceptibility to HIV infection (Valverde-Villegas et al., 2017b).

Understanding the effects of human genetic polymorphisms can also assist the choice of treatments and therapies against infections. For example, the HLA-B*5701 allele is associated with hypersensitivity reaction to the antiHIV drug Abacavir in certain ethnic groups (Mallal et al., 2002, 2008); hence, genotyping of this allele is part of standard HIV treatment care in developed countries and represents a good example of how human genetic factors can significantly influence the treatment of a given infection.

\section{Host genetics and vaccination}

Variable immune responses following immunization are linked, at least in part, to host genetic factors (Ellwanger and Chies, 2019). A study performed with West African population suggested that both HLA and non-HLA loci are responsible for the ability to respond to a vaccine (Newport et al., 2004). Some remarkable examples were observed concerning measles and hepatitis B vaccination. Response failure to measles vaccine has an important pattern associated with heritability and family clustering (Jacobson et al., 2003; Jacobson and Poland, 2004).
Also, different studies have shown that both antibody levels in response to hepatitis B vaccine and vaccine responsiveness are highly influenced by host genetics factors (Kruskall et al., 1992; Newport et al., 2004; Höhler et al., 2002). However, the impact of genetic features on vaccine immunogenicity is still a neglected topic (Ellwanger and Chies, 2019).

Genetic polymorphisms associated with protection from infectious diseases can also provide useful information for vaccine design through the strategy known as "reverse immunogenetics". For example, HLA alleles strongly associated with a particular phenotype may be used in immunoinformatic studies aiming to identify the best epitopes for inclusion in a particular vaccine (Davenport and Hill, 1996).

\section{SARS-CoV-2 as a study model}

SARS-CoV-2 is a novel single-stranded RNA betacoronavirus, which is responsible for the COVID-19 pandemic (Huang et al., 2020). On October 16, 2020, the pandemic had affected more than 39 million individuals worldwide (Dong et al., 2020; Johns Hopkins University, 2020). The COVID-19 has higher severity and mortality rates among elderly people and individuals with comorbidities, such as hypertension, diabetes, cardiovascular, and pulmonary diseases (Zhou F et al., 2020). Approximately $80 \%$ of infected individuals are adults with mild symptoms (Cao et al., 2020).

The main route of SARS-CoV-2 transmission is through respiratory droplets but individuals can also be infected through contact with surfaces and objects contaminated with the virus (Yang and Wang, 2020). To infect host cells, SARSCoV-2 viral spike glycoprotein interacts with the AngiotensinConverting Enzyme 2 (ACE2), which is expressed on the host cell membrane. Also, viral entry is mediated by the host cell serine protease TMPRSS2, which cleaves the viral spike protein, allowing the fusion of the viral particle and the host cell membrane (Hoffmann et al., 2020). A study has reported a higher ACE2 expression in the lungs of individuals with comorbidities compared to control individuals, reinforcing that individuals with comorbidities have a higher risk to progress to severe COVID-19 (Pinto et al., 2020).

Looking at the involvement of cytokines in the pathogenesis of COVID-19, increased interleukin 6 (IL6) levels are an important hallmark of severe COVID-19 cases, being associated with a higher risk of death (Chen et al., 2020; Del Valle et al., 2020; Herold et al., 2020; Zhou F et al., 2020). Deficient type I interferon (IFN) response was recently associated with an exacerbated inflammatory response in severe COVID-19 cases (Hadjadj et al., 2020). On the other hand, there is robust evidence indicating that an increased IFN response would be a factor responsible for severe COVID-19 (Lee et al., 2020; Lucas et al., 2020; Perlman, 2020). Due to these contradictory results, the role of IFN is an important target for basic research and clinical trials (Lee and Shin, 2020).

The clinical course of SARS-CoV-2 infection was characterized into 3 phases: phase 1, an asymptomatic incubation period with or without detectable virus; phase 2 , non-severe symptomatic clinical period with detectable virus; phase 3 , severe respiratory symptomatic clinical period with high viral load. It has been hypothesized that during the 
early clinical phase 2 , SARS-CoV-2 can cause non-severe symptoms and triggers protective immune responses. At this point of infection, the success of virus-eliminating immune response depends on the health status and genetic determinants potentially associated with susceptibility to SARS-CoV-2, such as HLA loci (Shi et al., 2020; Wang et al., 2020).

Previous existent databases including human genomes, polymorphisms and transcriptomic data are being explored to understand the potential role of host genetic factors on the susceptibility to SARS-CoV-2 infection and COVID-19 progression. Importantly, previous clinical data collected from SARS-CoV-2-related coronaviruses, such a SARS-CoV, is helping in providing insights into the role of host genetics on COVID-19. A recent study using expression quantitative trait loci (eQTL) database analyzed the cumulative effect of genetic variants on ACE2 and TMPRSS2 expression in individuals from five different human populations (African, American, European, East Asian and South Asian) from the 1000 Genomes project (Ortiz-Fernández and Sawalha, 2020). This study suggested that genetic polymorphisms are associated with reduced ACE2 and TMPRSS2 expression in African populations. This phenotype might be associated with less susceptibility to SARS-CoV-2 infection in such populations. Moreover, this finding could help explain the inter-individual variability observed in the COVID-19 clinical progression (Ortiz-Fernández and Sawalha, 2020). However, according to the analyzes of the $A C E 2$ gene carried out by Fam et al. (2020), most human populations are similarly susceptible to SARS-CoV-2.

The potential influence of HLA alleles on SARS-CoV-2 infection is being assessed. The HLA-B*46:01 allele was previously associated with SARS-CoV infection severity (Lin et al., 2003). In accordance, an in silico analysis found that HLA-B*46:01 allele predicted poor binding affinity for all SARS-CoV-2 peptides, suggesting an association of this allele with higher COVID-19 severity (Nguyen et al., 2020). A genome-wide association study (GWAS) performed by The Severe Covid-19 GWAS Group found that the $3 \mathrm{p} 21.31$ gene cluster (SLC6A20, LZTFL1, CCR9, FYCO1, CXCR6 and $X C R 1$; lead variant rs11385942) is a susceptibility locus for COVID-19-related respiratory failure (Ellinghaus et al., 2020). Furthermore, multiple evidence suggested that individuals with A blood group had higher risk of COVID-19 compared to individuals with non-A blood groups (Ellinghaus et al., 2020; Wu Y et al., 2020; Zhao et al., 2020). Although these results need to be replicated, they corroborate a role for genetics in the different clinical outcomes of COVID-19.

The international COVID-19 Host Genetics Initiative (https://www.covid19hg.org/) was recently created with the objective to collect, share and analyze host genetic data to understand the role of genetic determinants of susceptibility to SARS-CoV-2 infection and COVID-19 progression. Of note, homogenized protocols for phenotype clinical classification is highly important in studies addressing the immunogenetic aspects of infectious diseases. Also, bioinformatics approaches used for the prediction of candidate targets for immune response against SARS-CoV-2 contribute to vaccine designs (Grifoni et al., 2020). In this context, studies analyzing specific
HLA alleles associated with induction of protective immune response to SARS-CoV-2 are needed.

In recent years, the knowledge regarding the impact of host genetic factors on infectious diseases was enriched mainly by studies addressing HIV/AIDS, HCV, and HBV. The knowledge accumulated through these studies will help to understand how host genetics influence the susceptibility to SARS-CoV-2 infection and COVID-19 progression. Specifically, such studies can provide information regarding 1) potential polymorphisms associated with susceptibility or resistance to SARS-CoV-2 infection; 2) the identification of host genetic factors that modulate COVID-19 progression; 3) putative epitopes for vaccine design; 4) insights into potential therapies and SARS-CoV-2 pharmacogenetics.

\section{Actions focused on mitigation of outbreaks and epidemics}

In view of the public health risk posed by outbreaks, epidemics and pandemics, it is important that countries act together in undertaking measures to contain the spread of pathogens and mitigate diseases. Strategies such as travel restrictions, vaccination campaigns, surveillance and reporting of cases are examples of containment measures. When prevention and control measures are not met and an epidemic or pandemic event is established, it is important to focus on interventions to promote disease mitigation. The success of such measures relies on the participation of several stakeholders in all levels, including governments, institutions, communities and individuals. In addition, communication must be effective and clear in order to reach all levels of society, and hence broaden community awareness and participation (Schiavo et al., 2014; Oppenheim et al., 2018).

Different interventions can be applied depending on the infectious disease and the stakeholder group where they are implemented. For example, mitigation measures for Dengue include epidemiological surveillance and vector control, which depends not only on actions developed by environmental and health authorities, but also on educational campaigns, individual awareness and participation of the community (Gregianini et al., 2018). In the case of Yellow fever, for which a vaccine is available, vaccination campaigns and easy access to vaccines are effective prophylactic measures that depend on governmental authorities, healthcare settings and community acceptance. Another example of effective intervention to mitigate vector-borne disease at the community level is the use of insecticide-treated bednets in malaria-endemic areas (Yang et al., 2018).

The pandemic risk posed by new influenza viruses has led the World Health Organization to create strategies for the prevention, surveillance and control of influenza. As part of the Global Influenza Surveillance and Response System (GISRS), launched in 1952, initiatives such as the Global Influenza Program (GIP), the Pandemic Influenza Preparedness (PIP), and the Global Influenza Strategy 2019-2030 have been essential for epidemiological surveillance and development of diagnostic tools, vaccines and antivirals against influenza, as well as for building up laboratory capacity and capabilities to increase the number of tested individuals (Hay and McCauley, 2018; WHO, 2019). The benefits of these programs surpass 
influenza epidemics, since respiratory infections may also be caused by other viruses, some of which associated to severe disease, such as the highly pathogenic coronaviruses SARS-CoV, MERS-CoV and, more recently, SARS-CoV-2 (Guarner, 2020).

The emergence of the SARS-CoV-2 at the end of 2019 was not dealt with equally by the authorities of different countries: while some governments promptly responded by closing borders, establishing lockdown and social distancing procedures, and testing individuals, others disregarded the severity and transmissibility of COVID-19. As a consequence, in few weeks COVID-19 had been declared a pandemic (WHO, 2020d) and, as previously mentioned, on October 16, 2020, more than 39 million cases of COVID-19 have been confirmed worldwide, including over 1 million deaths (Dong et al., 2020; Johns Hopkins University, 2020).

If on the one hand countries failed in containing the spread of SARS-CoV-2, on the other hand, due to the 2009 influenza pandemic, many countries were prepared for implementing mitigation actions. For example, in Brazil, reference laboratories that are part of the National Influenza Network were already equipped for laboratorial analyses of respiratory viral infection, hence were able to perform molecular analyses of samples from patients suspected of SARS-CoV-2 infection; with the advance of the disease in the country, other healthcare setting, including hospitals and private laboratories, also started to test individuals. In addition to governmental policies and community adoption of quarantine and social distancing behaviors, the world scientific community quickly responded to the emergence of the novel coronavirus by rapidly sequencing its genome, developing diagnostic kits, searching for drugs with antiviral activities against SARS-CoV-2 or able to alleviate COVID-19 symptoms.

Technological advances significantly contribute to the improvement of mitigation strategies. As mentioned, few days after SARS-CoV-2 was identified as the etiological agent of the severe pneumonia cases that had started at the end of 2019, scientists were able to sequence and analyze its genome, using deep sequencing and bioinformatic tools (Zhu et al., 2020). Based on the genome sequence, diagnostic assays were promptly implemented and are being improved.

Other international initiatives have been created for mitigating infectious diseases. Of note, the WIPO Re:Search Consortium was launched by the WHO and the World Intellectual Property Organization (WIPO) to accelerate the development of vaccines, diagnostic tools and drug research and development for neglected tropical diseases - mainly parasitic, bacterial and viral infections - through innovative research partnership and the sharing of knowledge and intellectual property among its members, which include universities and other scientific research institutions, as well as biotechnology and pharmaceuticals companies (WIPO, 2019). Such an initiative contributes to mitigating infectious diseases not only because it catalyzes biomedical and biotechnological innovations, but also because it engages scientists to get involved in projects to address unmet medical needs for some infectious diseases.
Other mitigation strategies rely on advances in information technologies; for example, mobile phone data provides information about individual's spatial behavior and mobility (Rubrichi et al., 2018); health system databases and the internet contribute for notification of new cases, and higher computer capacity enables development of mathematical models to predict epidemic curves; mobile phones and other personal devices are also useful for notification of cases and healthcare support during social isolation. Finally, governmental actions to mitigate infectious diseases are important but have little impact without the acceptance and involvement of the community and other stakeholders.

\section{Conservation of ecosystems as a public health strategy}

There is an urgent need for an international, targeted, and well-coordinated action plan for the conservation of global ecosystems (Watson et al., 2020). Actions for environmental preservation are mainly focused on the protection of threatened species and mitigation of climate change. We would like to add that prevention of infectious disease outbreaks is an additional benefit to conservation efforts. This strategy is well accepted by the scientific community but rarely used as an important argument in defense of environmental policies. Acknowledging this scenario can bring many benefits to society, and we urge all members of the scientific community to publicize and disseminate this information. In our opinion, awareness of the connections between ecosystems and the emergence/spread of infectious diseases will help to mobilize decision-makers and civil society in favor of the conservation agenda, especially considering the current scenario, with the ongoing COVID-19 pandemic.

In Brazil, government actions focused on the environment have been greatly weakened (Carvalho et al., 2019; Ferrante and Fearnside, 2019; Hope, 2019). Currently, deforestation and other environmental disturbances in the Amazon region are growing (Artaxo, 2019; Escobar, 2019; INPE, 2020; Matricardi et al., 2020), and attempts to facilitate the hunting of wild animals are on the rise (WWF, 2019). Deforestation and other environmental disturbances are associated with the emergence and spread of different infections (Ellwanger et al., 2020a). Therefore, conservation efforts must be presented to everyone, from the lay public to specialized professionals and governments as concrete and effective public health measures, capable of avoiding cases of many vector-borne infections.

Handling of bushmeat, for example, facilitates spillover events that can introduce new pathogens into the human population, as happened with HIV (Hahn et al., 2000) and potentially with the current COVID-19 (Zhang and Holmes, 2020), representing an additional reason to limit hunting of wild animals. Of note, these points must be mentioned when drafting laws and regulations focused on the preservation of wild species. Otherwise, we should ask: What are we learning from these situations? Put in simple, conservation of ecosystems is a public health issue and scientists have a key role to play in disseminating this pivotal information.

Infectious diseases following natural disasters 
Natural disasters with atmospheric, geological, and hydrological origins are disruptions of the ecological system that impact the harmonious relationship of human societies with the environment and other species (Lemonick, 2011). Disasters include drought, landslides, earthquakes, volcanic eruptions, floods, hurricanes, and tsunamis, and they have serious social, economic and health consequences (Watson et al., 2007). Disaster-preparedness systems are important in order to reduce the public health impact during and following a disaster; however, many low- and middleincome communities living in areas more susceptible to natural disasters lack infrastructure, resources and disasterresponse plans (Lemonick, 2011). In addition, poverty and social inequality, as well as environmental degradation and rapid population growth are characteristics of vulnerable communities that contribute for disaster severity. Of note, most deaths associated with natural disasters are due to fractures, burn, blunt trauma, drowning and crush-related injuries; communicable diseases after natural disasters are less common and are usually associated with after-effects of the disaster, which includes environmental changes, population displacement, proliferation of (and exposure to) disease vectors, poor water and sanitation conditions, poor food supply, limited access to healthcare services, lack of health professionals and other human resources (Watson et al., 2007; Kouadio et al., 2012).

The infectious diseases that most commonly occur during or after a natural disaster are diarrhea, acute respiratory infections, measles, cholera, and leptospirosis. Of note, crowding due to population displacement during a disaster contribute for the spread of diseases that are transmitted person-to-person by airborne droplets, such as respiratory infections - both bacterial (e.g., tuberculosis, pertussis, Legionella) and viral (e.g., influenza, respiratory syncytial virus, measles, coronaviruses, and others) (Lemonick, 2011).

During the occurrence of a disaster and the first 0-4 days that follow it, emergency services are the most required. Approximately 4 weeks after the disaster, during the recovery phase, there is an increased risk for the occurrence of diseases with a longer incubation period, as well as vector-borne diseases and chronic diseases; hence, surveillance strategies are important for the prevention of outbreaks, epidemics or, in a worst case scenario, pandemics. Examples are outbreaks of disease resulting from the displacement of people in overcrowded fields and cross-contamination of water sources with fecal material and toxic products (Lemonick, 2011; Kouadio et al., 2012).

As above-mentioned, one of the main factors that aggravate these outbreaks is socio-environmental vulnerability. For example, every year intense precipitation causes floods and land sliding in different regions of Brazil. Accordingly, in 2013 the state of Acre, located in Northern Brazil and that has a low human development index, experienced serious rainfalls that were followed by outbreaks of leptospirosis; whereas in the Southern state of Santa Catarina, which has a high human development index and also suffered severe rainfalls in 2013, cases of leptospirosis did not increase significantly (S2iD, 2013).
Another example is the cholera outbreak in Haiti that occurred 10 months after the 2010 earthquake. While approximately 200,000 people died in the disaster, 665,000 cases of cholera were reported, with 8,183 deaths (CDC, 2014). Notably, the country was collapsed by the earthquake: public health services structures had been reduced by damage and loss, there was a lack in infrastructure and sanitation systems, and work teams were still focused on caring for victims - the perfect storm for the cholera epidemic (Fraser, 2010; Gelting et al., 2013).

These examples show that, when planning for the response to natural disasters, emergency services must define the strategies to monitor and contain disease outbreaks that arise weeks after the disaster. Such actions require post-disaster surveillance systems able to quickly detect cases of epidemicprone diseases (Watson et al. 2007). If not contained, an outbreak that follows a disaster can turn a local problem into a regional or national epidemic. Moreover, developed countries should support developing countries in these strategies to respond to natural disasters that include the supply of vaccines, medical supplies, training of health professionals and efficient health surveillance systems.

\section{Translational ecology: practical actions, economic fund and political engagement for the control and prevention of infectious diseases}

A higher number of people must recognize the preservation of biodiversity and ecosystems as an effective strategy for the prevention and control of infectious diseases. This strategy must be spread among the lay population and scientists from various fields. However, this strategy will only have practical results if applied in a systematic and lasting way, considering medical, economic and social aspects of the populations. Therefore, translational ecology is needed: knowledge and scientific data must be transformed into public policies and laws focused on the protection of biodiversity and ecosystems (Schlesinger, 2010; Enquist et al., 2017; Sokolow et al., 2019; Ellwanger et al., 2020a; Xiao and Torok, 2020). Engaging politicians and decision-makers in discussions about the influence of the environment on the dynamics of infectious diseases is essential for translational ecology to be part of the political agenda of government agencies at local and national levels.

Creating economic strategies to deal with public health emergencies is also essential. In this sense, high-income countries should create a stock capital fund to help poor countries tackle emerging epidemics. Besides the humanitarian issue per se, by helping to mitigate or prevent the emergence of epidemics in less favored nations, high-income countries end up preventing such epidemics from reaching their territories, avoiding the socioeconomic impacts generated in a context of epidemic or pandemic. In fact, societal initiatives have already been created, but they are difficult to sustain during "inter-pandemic" periods. Furthermore, in addition to creating an investment fund to prevent epidemics and pandemics, it is extremely important to know where and how these financial resources should be applied (Yamey et al., 2017; Berry et al., 2018). 
Investments in the prevention of outbreaks and epidemics encompass hospitals, lab facilities and equipment, vehicles, surveillance networks, knowledge, and human capital. Such investments represent an economically advantageous strategy to follow, especially when compared to the high costs to mitigate the effects of epidemics and pandemics. Considering the current issues regarding climate change and biodiversity loss, outbreaks and epidemics are becoming increasingly common, especially in tropical countries. For these reasons, countries should use "inter-epidemic" periods to prepare themselves economically to deal with epidemic and pandemic periods (Morse et al., 2012; Berry et al., 2018; Dobson et al., 2020).

The scenario mentioned above reinforces the need for international cooperation to avoid and deal with emerging infectious diseases. International funds focused on the prevention and control of infectious diseases is an urgent necessity (Ross et al., 2015; Dobson et al., 2020; Jia and Wu, 2020). In addition, scientific evidence showing the association of biodiversity loss and climate change with outbreaks and epidemics needs to be transformed into public policies focused on protecting the environment.

\section{Final considerations}

The multiple interactions between humans and pathogens can be facilitated or avoided depending on the presence or absence of actions for the control and prevention of infectious diseases. Host genetic factors also interfere with host-pathogen interactions, since the genetic background modifies susceptibility to infections and disease progression (Figure 2). Of note, this article highlights that the effects of human genetics on the susceptibility and progression of infectious diseases are expressed within a complex context, where biological and social factors are playing important roles in the disease.

Robust evidence shows that the initiatives here addressed are crucial for the control and prevention of human infectious diseases. Scientists have a fundamental role in the search for alternatives to improve these initiatives. These professionals must also act on the dissemination of the importance of these

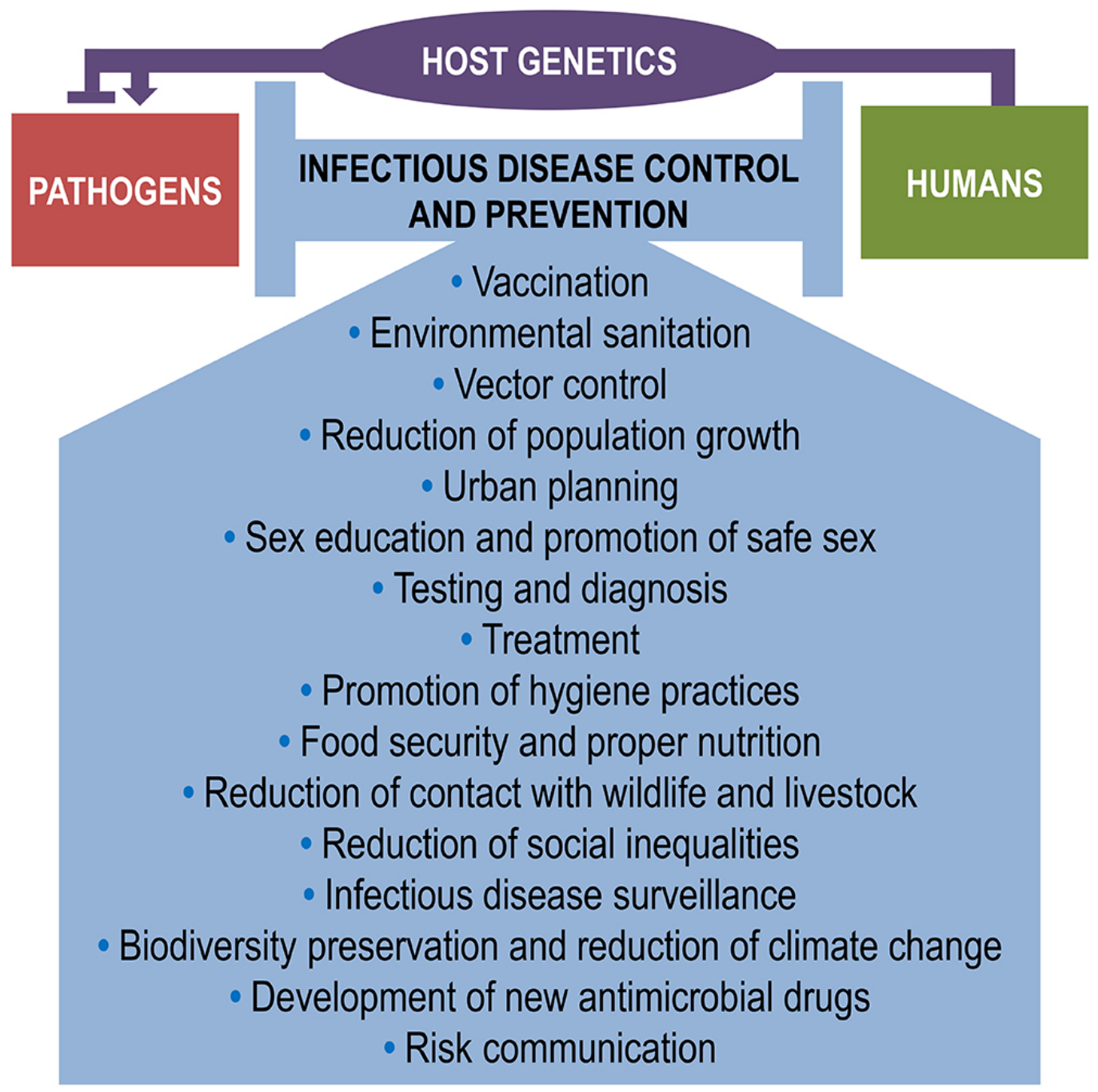

Figure 2 - Actions for infectious disease control and prevention. The interactions between humans and pathogens can be facilitated or avoided depending on the presence or absence of actions of control and prevention of infectious diseases. Moreover, host genetics affects host-pathogen interactions: for example, HLA alleles and genetic polymorphisms can increase or decrease susceptibility to infectious diseases. These genetic traits also affect the progression of infectious diseases. This figure is based on references and discussions mentioned throughout the article. 
actions, especially in the most vulnerable populations and regions.

Considering the multiplicity of the actions for the control and prevention of infectious diseases, it is necessary to engage professionals from different fields. For example, biologists may commit to the development of new vector control tools and also be involved in the detection of host genetic factor associated with infectious disease phenotypes; veterinarians can contribute for surveillance of pathogenic agents such as protozoa, virus and bacteria in wild and domestic animals; social scientists can act on the identification of populations most vulnerable to infections; geneticists and molecular biologists can improve methods for pathogen detection; and medical scientists can develop better therapies. In other words, the control of infectious diseases must be performed within the One Health perspective, considering human, animal, and environmental drivers of infections. The boundaries between humans and non-human animals must be prioritized, as they are critical for the emergence of new human diseases. Therefore, epidemiological surveillance actions involving human-animal interactions and sanitary control in meat markets are essential for the prevention and control of new infectious diseases.

The application of the actions discussed here requires a significant amount of financial resources and the involvement of civil society and government institutions. To achieve these goals, the participation of politicians committed to public policies focused on the environment and health promotion is fundamental. The lack of connection between scientific research and public policies is the reason that often explains why there are flaws in the control of infectious diseases, even though there are already prevention and treatment strategies for many of them.

Finally, this article has pointed out the best directions that researchers and decision-makers committed with the control of infectious diseases must follow to perform research activities and promote health among society in a realistic and evidence-based way. Properly selecting the areas and initiatives that best fit the aspirations of researchers and the needs of each population help to optimize the financial resources for infectious disease control initiatives and research focused on pathogens, especially in developing countries where the resources are limited.

\section{Acknowledgments}

JHE receives a postdoctoral fellowship from Coordenação de Aperfeiçoamento de Pessoal de Nível Superior (Programa Nacional de Pós-Doutorado - PNPD/ CAPES, Brazil). VLK receives a postdoctoral fellowship from Fundação de Amparo à Pesquisa do Estado de São Paulo (FAPESP, Brazil). ABGV and JABC receive research fellowships from Conselho Nacional de Desenvolvimento Cientifico e Tecnológico (CNPq, Brazil). JABC also receives funding from CAPES (Brazil).

\section{Conflicts of interest}

Abner Willian Quintino de Freitas is CEO of Pedra Circular, a startup of risk management in disasters, Brazil. Jacqueline María Valverde-Villegas is a researcher at Laboratoire coopératif IGMM/ABIVAX, Institut de Génétique
Moléculaire de Montpellier (IGMM), Centre National de la Recherche Scientifique (CNRS), Montpellier, France. No other conflict of interest to declare.

\section{Author contributions}

JHE, ABGV, VLK, JMVV and AWQF wrote the initial version of the manuscript. JABC and JHE revised and edited the text.

\section{References}

Abou Tayoun AN, Burchard PR, Malik I, Scherer A and Tsongalis GJ (2014) Democratizing molecular diagnostics for the developing world. Am J Clin Pathol 141:17-24.

Adane M, Mengistie B, Kloos H, Medhin G and Mulat W (2017) Sanitation facilities, hygienic conditions, and prevalence of acute diarrhea among under-five children in slums of Addis Ababa, Ethiopia: Baseline survey of a longitudinal study. PLoS One 12:e0182783.

Ahmed F, Ahmed N, Pissarides C and Stiglitz J (2020) Why inequality could spread COVID-19. Lancet Public Health 5:e240.

Aiello AE and Larson EL (2002) What is the evidence for a causal link between hygiene and infections? Lancet Infect Dis 2:103-110.

Akhtar F, Lodhi SA, Khan SS and Sarwar F (2016) Incorporating permaculture and strategic management for sustainable ecological resource management. J Environ Manage 179:31-37.

Allen RH (2007) The role of family planning in poverty reduction. Obstet Gynecol 110:999-1002.

Allen SJ, O'Donnell A, Alexander NDE, Alpers MP, Peto TEA, Clegg JB and Weatherall DJ (1997) $\alpha^{+}$-Thalassemia protects children against disease caused by other infections as well as malaria. Proc Natl Acad Sci U S A 94:14736-14741.

Alonso P, Engels D and Reeder J (2017) Renewed push to strengthen vector control globally. Lancet 389:2270-2271.

Alvar J, Yactayo S and Bern C (2006) Leishmaniasis and poverty. Trends Parasitol 22:552-557.

Artaxo P (2019) Working together for Amazonia. Science 363:323.

Bahl R, Bhandari N, Hambidge KM and Bhan MK (1998) Plasma zinc as a predictor of diarrheal and respiratory morbidity in children in an urban slum setting. Am J Clin Nutr 68:414S-417S

Banoo S, Bell D, Bossuyt P, Herring A, Mabey D, Poole F, Smith PG, Sriram N, Wongsrichanalai C, Linke R, et al. (2006) Evaluation of diagnostic tests for infectious diseases: general principles. Nat Rev Microbiol 4:S21-S31.

Bañuls AL, Thomas F and Renaud F (2013) Of parasites and men. Infect Genet Evol 20:61-70.

Barbeito-Andrés J, Pezzuto P, Higa LM, Dias AA, Vasconcelos JM, Santos TMP, Ferreira JCCG, Ferreira RO, Dutra FF, Rossi $\mathrm{AD}$, et al. (2020) Congenital Zika syndrome is associated with maternal protein malnutrition. Sci Adv 6:eaaw6284.

Bedford J, Farrar J, Ihekweazu C, Kang G, Koopmans M and Nkengasong J (2019) A new twenty-first century science for effective epidemic response. Nature 575:130-136.

Berry K, Allen T, Horan RD, Shogren JF, Finnoff D and Daszak P (2018) The economic case for a pandemic fund. Ecohealth 15:244-258.

Bogowicz P, Moore D, Kanters S, Michelow W, Robert W, Hogg R, Gustafson R, Gilbert M and ManCount Study Team (2016) HIV testing behaviour and use of risk reduction strategies by HIV risk category among MSM in Vancouver. Int J STD AIDS 27: 281-287.

Bhaskaram P (2002) Micronutrient malnutrition, infection, and immunity: an overview. Nutr Rev 60:S40-S45.

Bhutta ZA, Sommerfeld J, Lassi ZS, Salam RA and Das JK (2014) Global burden, distribution, and interventions for infectious diseases of poverty. Infect Dis Poverty 3:21. 
Bianchini J, Humblet M, Cargnel M, der Stede YV, Koenen F, de Clercp K and Saegerman C (2019) Prioritization of livestock transboundary diseases in Belgium using a multicriteria decision analysis tool based on drivers of emergence. Transbound Emerg Dis 67:344-376.

Blackwell JM, Jamieson SE and Burgner D (2009) HLA and infectious diseases. Clin Microbiol Rev 22:370-385.

Bonan GB (2008) Forests and climate change: forcings, feedbacks, and the climate benefits of forests. Science 320:1444-1449.

Boni MF, Lemey P, Jiang X, Lam TTY, Perry BW, Castoe TA, Rambaut A and Robertson DL (2020) Evolutionary origins of the SARS-CoV-2 sarbecovirus lineage responsible for the COVID-19 pandemic. Nat Microbiol 5:1408-1417

Bronzwaer SLAM, Cars O, Buchholz U, Mölstad S, Goettsch W, Veldhuijzen IK, Kool JL, Sprenger MJW, Degener JE, et al. (2002) A European study on the relationship between antimicrobial use and antimicrobial resistance. Emerg Infect Dis 8:278-282.

Brown IH (2001) The pig as an intermediate host for influenza A viruses between birds and humans. Int Congr 1219:173-178.

Buhaug H and Urdal H (2013) An urbanization bomb? Population growth and social disorder in cities. Global Environ Chang 23:1-10

Bühler HF, Ignotti E, Neves SMAS and Hacon SS (2014) Análise espacial de indicadores integrados de saúde e ambiente para morbimortalidade por diarreia infantil no Brasil, 2010. Cad Saude Publica 30:1921-1934.

Calistri P, Iannetti S, Danzetta ML, Narcisi V, Cito F, Di Sabatino D, Bruno R, Sauro F, Atzeni M, Carvelli A, et al. (2013) The components of 'One World - One Health' approach. Transbound Emerg Dis 60:4-13.

Cao Q, Chen YC, Chen CL and Chiu CH (2020) SARS-CoV-2 infection in children: Transmission dynamics and clinical characteristics. J Formos Med Assoc 119:670-673.

Candido DS, Claro IM, de Jesus JG, Souza WM, Moreira FRR, Dellicour S, Mellan TA, du Plessis L, Pereira RHM, Sales FCS, et al. (2020) Evolution and epidemic spread of SARSCoV-2 in Brazil. Science 369:1255-1260.

Carvalho WD, Mustin K, Hilário RR, Vasconcelos IM, Eilers V and Fearnside PM (2019) Deforestation control in the Brazilian Amazon: A conservation struggle being lost as agreements and regulations are subverted and bypassed. Perspect Ecol Conser 17:122-130.

Casanova JL and Abel L (2013) The genetic theory of infectious diseases: a brief history and selected illustrations. Annu Rev Genomics Hum Genet 14:215-243.

Casanova JL and Abel L (2020) The human genetic determinism of life-threatening infectious diseases: genetic heterogeneity and physiological homogeneity? Hum Genet 139:681-694.

Castrucci MR, Donatelli I, Sidoli L, Barigazzi G, Kawaoka Y and Webster RG (1993) Genetic reassortment between avian and human influenza A viruses in italian pigs. Virology 193:503506.

Cegielski JP and McMurray DN (2004) The relationship between malnutrition and tuberculosis: evidence from studies in humans and experimental animals. Int J Tuberc Lung Dis 8:286-298.

Chen X, Zhao B, Qu Y, Chen Y, Xiong J, Feng Y, Men D, Huang Q, Liu Y, Yang B, et al. (2020) Detectable serum SARS-CoV-2 viral load (RNAaemia) is closely correlated with drastically elevated interleukin 6 (IL-6) level in critically ill COVID-19 patients. Clin Infect Dis. 71:1937-1942

Chomel BB, Belotto A and Meslin FX (2007) Wildlife, exotic pets, and emerging zoonoses. Emerg Infect Dis 13:6-11.
Chopera DR, Woodman Z, Mlisana K, Mlotshwa M, Martin DP, Seoighe C, Treurnicht F, de Rosa DA, Hide W, Karim SA, et al. (2008) Transmission of HIV-1 CTL escape variants provides HLA-mismatched recipients with a survival advantage. PLoS Pathog 4:e1000033.

Cifuentes E and Rodriguez S (2005) Urban sprawl, water insecurity, and enteric diseases in children from Mexico city. EcoHealth 2:70-75.

Coates A, Hu Y, Bax R and Page C (2002) The future challenges facing the development of new antimicrobial drugs. Nat Rev Drug Discov 1:895-910.

Cohen MS, Chen YQ, McCauley M, Gamble T, Hosseinipour MC, Kumarasamy N, Hakim JG, Kumwenda J, Grinsztejn B, Pilotto $\mathrm{JH}$, et al. (2011) Prevention of HIV-1 infection with early antiretroviral therapy. N Engl J Med 365:493-505.

Cohen MS, Chen YQ, McCauley M, Gamble T, Hosseinipour MC, Kumarasamy N, Hakim JG, Kumwenda J, Grinsztejn B, Pilotto $\mathrm{JH}$, et al. (2016) Antiretroviral therapy for the prevention of HIV-1 transmission. N Engl J Med 375:830-839.

Cohen MS, Gamble T and McCauley M (2020) Prevention of HIV transmission and the HPTN 052 study. Annu Rev Med 71:347360.

Coltart CEM, Lindsey B, Ghinai I, Johnson AM and Heymann DL (2017) The Ebola outbreak, 2013-2016: old lessons for new epidemics. Philos Trans R Soc Lond B Biol Sci 372:20160297.

Corburn J (2015) City planning as preventive medicine. Prev Med 77:48-51.

Crist E, Mora C and Engelman R (2017) The interaction of human population, food production, and biodiversity protection. Science 356:260-264.

Cunningham AA, Daszak P and Wood JLN (2017) One Health, emerging infectious diseases and wildlife: two decades of progress? Philos Trans R Soc Lond B Biol Sci 372:20160167.

Dalziel BD, Kissler S, Gog JR, Viboud C, Bjørnstad ON, Metcalf CJE and Grenfell BT (2018) Urbanization and humidity shape the intensity of influenza epidemics in U.S. cities. Science 362:75-79.

Da Silva GK, Vianna P, Veit TD, Crovella S, Catamo E, Cordero EA, Mattevi VS, Lazzaretti RK, Sprinz E, Kuhmmer R, et al. (2014) Influence of HLA-G polymorphisms in human immunodeficiency virus infection and hepatitis $\mathrm{C}$ virus coinfection in Brazilian and Italian individuals. Infect Genet Evol 21:418-423.

Davenport MP and Hill AVS (1996) Reverse immunogenetics: from HLA-disease associations to vaccine candidates. Mol Med Today 2:38-45.

Daszak P, Cunningham AA and Hyatt AD (2000) Emerging infectious diseases of wildlife--threats to biodiversity and human health. Science 287:443-449.

Daszak P, Olival KJ and Li H (2020) A strategy to prevent future epidemics similar to the 2019-nCoV outbreak. Biosaf Health 2:6-8.

Degroote S, Zinszer K and Ridde V (2018) Interventions for vectorborne diseases focused on housing and hygiene in urban areas: a scoping review. Infect Dis Poverty 7:96.

Del Valle DM, Kim-Schulze S, Huang HH, Beckmann ND, Nirenberg S, Wang B, Lavin Y, Swartz TH, Madduri D, Stock A, et al. (2020) An inflammatory cytokine signature predicts COVID-19 severity and survival. Nat Med 26:1636-1643.

Dobson AP, Pimm SL, Hannah L, Kaufman L, Ahumada JA, Ando AW, Bernstein A, Busch J, Daszak P, Engelmann J, et al. (2020) Ecology and economics for pandemic prevention. Science 369:379-381. 
Dong E, Du H and Gardner L (2020) An interactive web-based dashboard to track COVID-19 in real time. Lancet Infect Dis 20:533-534.

Dutta M, Dutta P, Medhi S, Borkakoty B and Biswas D (2018) Polymorphism of HLA class I and class II alleles in influenza $\mathrm{A}(\mathrm{H} 1 \mathrm{~N} 1) \mathrm{pdm} 09$ virus infected population of Assam, Northeast India. J Med Virol 90:854-860.

Echazú A, Bonanno D, Juarez M, Cajal SP, Heredia V, Caropresi S, Cimino RO, Caro N, Vargas PA, Paredes G, et al. (2015) Effect of poor access to water and sanitation as risk factors for soil-transmitted helminth infection: selectiveness by the infective route. PLoS Negl Trop Dis 9:e0004111.

Egan ES (2018) Beyond hemoglobin: screening for malaria host factors. Trends Genet 34:133-141.

Ellinghaus D, Degenhardt F, Bujanda L, Buti M, Albillos A, Invernizzi P, Fernández J, Prati D, Baselli G, Asselta R, et al. (2020) Genomewide association study of severe Covid-19 with respiratory failure. N Engl J Med 383:1522-1534.

Ellwanger JH (2019) Fatores imunogenéticos e ambientais envolvidos no estabelecimento de doenças virais emergentes, reemergentes e negligenciadas no Brasil - Um enfoque na perspectiva One Health. Doctoral Thesis, Programa de Pós-Graduação em Genética e Biologia Molecular, Universidade Federal do Rio Grande do Sul, Porto Alegre, Brazil 280 p.

Ellwanger JH and Chies JAB (2018a) Zoonotic spillover and emerging viral diseases - time to intensify zoonoses surveillance in Brazil. Braz J Infect Dis 22:76-78.

Ellwanger JH and Chies JAB (2018b) Wind: a neglected factor in the spread of infectious diseases. Lancet Planet Health 2:e475.

Ellwanger JH and Chies JAB (2019) Host genetic factors can impact vaccine immunogenicity and effectiveness. Lancet Infect Dis 19:359-360.

Ellwanger JH, Kaminski VL and Chies JAB (2017) How to detect new viral outbreaks or epidemics? We need to survey the circulation of viruses in humans and other animals using fast, sensible, cheap, and broad-spectrum methodologies. Braz J Infect Dis 21:211-212.

Ellwanger JH, Kaminski VL and Chies JAB (2019) Emerging infectious disease prevention: Where should we invest our resources and efforts? J Infect Public Health 12:313-316.

Ellwanger JH, Kulmann-Leal B, Kaminski VL, Valverde-Villegas JM, da Veiga ABG, Spilki FR, Fearnside PM, Caesar L, Giatti LL, Wallau GL, et al. (2020a) Beyond diversity loss and climate change: Impacts of Amazon deforestation on infectious diseases and public health. An Acad Bras Cienc 92:e20191375

Ellwanger JH, Kaminski VL, Rodrigues AG, Kulmann-Leal B and Chies JAB (2020b) CCR5 and CCR5 32 in bacterial and parasitic infections: Thinking chemokine receptors outside the HIV box. Int J Immunogenet 47:261-285.

Ellwanger JH, Kulmann-Leal B, Wolf JM, Michita RT, Simon D, Lunge VR and Chies JAB (2020c) Role of the genetic variant CCR5 32 in HBV infection and HBV/HIV co-infection. Virus Res 277:197838.

Ellwanger JH, Prá D, Rieger A and Franke SIR (2011) Influência do estado nutricional de selênio sobre a progressão da infecção pelo HIV. Nutrire 36:109-122.

Enquist CAF, Jackson ST, Garfin GM, Davis FW, Gerber LR, Littell JA, Tank JL, Terando AJ, Wall TU, Halpern B, et al. (2017) Foundations of translational ecology. Front Ecol Environ 15:541-550.

Escobar H (2019) Amazon fires clearly linked to deforestation, scientists say. Science 365:853.

Eskew EA and Olival KJ (2018) De-urbanization and zoonotic disease risk. Ecohealth 15:707-712.

Espinosa R, Tago D and Treich N (2020) Infectious diseases and meat production. Environ Resource Econ 76:1019-1044.
Fam BSO, Vargas-Pinilla P, Amorim CEG, Sortica VA and Bortolini MC (2020) ACE2 diversity in placental mammals reveals the evolutionary strategy of SARS-CoV-2. Genet Mol Biol 43:e20200104.

Faria NR, Quick J, Claro IM, Thézé J, de Jesus JG, Giovanetti M, Kraemer MUG, Hill SC, Black A, da Costa AC, et al. (2017) Establishment and cryptic transmission of Zika virus in Brazil and the Americas. Nature 546:406-410.

Farmer P (1996) Social inequalities and emerging infectious diseases. Emerg Infect Dis 2:259-269.

Fearnside PM (2008) Amazon Forest maintenance as a source of environmental services. An Acad Bras Cienc 80:101-114.

Ferrante L and Fearnside PM (2019) Brazil's new president and 'ruralists' threaten Amazonia's environment, traditional peoples and the global climate. Environ Conserv 46:261-263.

Friant S, Ayambem WA, Alobi AO, Ifebueme NM, Otukpa OM, Ogar DA, Alawa CBI, Goldberg TL, Jacka JK and Rothman JM (2020) Eating bushmeat improves food security in a biodiversity and infectious disease "hotspot". Ecohealth 17:125-138.

Flaxman S, Mishra S, Gandy A, Unwin HJT, Mellan TA, Coupland $\mathrm{H}$, Whittaker C, Zhu H, Berah T, Eaton JW, et al. (2020) Estimating the effects of non-pharmaceutical interventions on COVID-19 in Europe. Nature 584:257-261.

Flores HA and O'Neill SL (2018) Controlling vector-borne diseases by releasing modified mosquitoes. Nat Rev Microbiol 16:508-518.

Fonner VA, Dalglish SL, Kennedy CE, Baggaley R, O’Reilly KR, Koechlin FM, Rodolph M, Hodges-Mameletzis I and Grant RM (2016) Effectiveness and safety of oral HIV preexposure prophylaxis for all populations. AIDS 30:1973-1983.

Ford JV, Ivankovich MB, Douglas JM Jr, Hook EW 3rd, Barclay L, Elders J, Satcher D and Coleman E (2017) The need to promote sexual health in America: a new vision for public health action. Sex Transm Dis 44:579-585.

Foroughi M, Moayedi-Nia S, Shoghli A, Bayanolhagh S, Sedaghat A, Mohajeri M, Mousavinasab SN and Mohraz M (2017) Prevalence of HIV, HBV and HCV among street and labour children in Tehran, Iran. Sex Transm Infect 93: 421-423.

Fraser B (2010) Haiti still gripped by cholera as election looms. Lancet 376:1813-1814.

Freeman MC, Garn JV, Sclar GD, Boisson S, Medlicott K, Alexander KT, Penakalapati G, Anderson D, Mahtani AG, Grimes JET, et al. (2017) The impact of sanitation on infectious disease and nutritional status: A systematic review and meta-analysis. Int J Hyg Environ Health 220:928-949.

French RK and Holmes EC (2020) An ecosystems perspective on virus evolution and emergence. Trends Microbiol 28:165-175.

Fuente D, Allaire M, Jeuland M and Whittington D (2020) Forecasts of mortality and economic losses from poor water and sanitation in sub-Saharan Africa. PLoS One 15:e0227611.

Gao F, Bailes E, Robertson DL, Chen Y, Rodenburg CM, Michael SF, Cummins LB, Arthur LO, Peeters M, Shaw GM, et al. (1999) Origin of HIV-1 in the chimpanzee Pan troglodytes troglodytes. Nature 397:436-441.

Gardy JL and Loman NJ (2018) Towards a genomics-informed, real-time, global pathogen surveillance system. Nat Rev Genet 19:9-20.

GBD 2017 Disease and Injury Incidence and Prevalence Collaborators (2018) Global, regional, and national incidence, prevalence, and years lived with disability for 354 diseases and injuries for 195 countries and territories, 1990-2017: a systematic analysis for the Global Burden of Disease Study 2017. Lancet 392:1789-1858.

Gelting R, Bliss K, Patrick M, Lockhart G and Handzel T (2013) Water, sanitation and hygiene in Haiti: past, present, and future. Am J Trop Med Hyg 89:665-670. 
Geoghegan JL and Holmes EC (2017) Predicting virus emergence amid evolutionary noise. Open Biol 7:170189.

Gibb R, Redding DW, Chin KQ, Donnelly CA, Blackburn TM, Newbold T and Jones KE (2020) Zoonotic host diversity increases in human-dominated ecosystems. Nature 584:398402.

Giles-Corti B, Vernez-Moudon A, Reis R, Turrell G, Dannenberg AL, Badland H, Foster S, Lowe M, Sallis JF, Stevenson M, et al. (2016) City planning and population health: a global challenge. Lancet 388:2912-2924.

Glamann J, Hanspach J, Abson DJ, Collier N and Fischer J (2017) The intersection of food security and biodiversity conservation: a review. Reg Environ Change 17:1303-1313.

Gomes da Silva FJ and Gouveia RM (2020) Global population growth and industrial impact on the environment. In: Gomes da Silva FJ and Gouveia RM (eds) Cleaner Production. Springer Nature, Cham, Switzerland, pp 33-75.

Gostin LO, Hodge JG Jr, Bloom BR, El-Mohandes A, Fielding J, Hotez P, Kurth A, Larson HJ, Orenstein WA, Rabin K, et al. (2020) The public health crisis of underimmunisation: a global plan of action. Lancet Infect Dis 20:e11-e16.

Grant RM, Lama JR, Anderson PL, McMahan V, Liu AY, Vargas L, Goicochea P, Casapía M, Guanira-Carranza JV, RamirezCardich ME, et al. (2010) Preexposure chemoprophylaxis for HIV prevention in men who have sex with men. N Engl J Med 363:2587-2599.

Greene VW (2001) Personal hygiene and life expectancy improvements since 1850: historic and epidemiologic associations. Am J Infect Control 29:203-206.

Gregianini TS, Tumioto-Giannini GL, Favreto C, Plentz LC, Ikuta N and Veiga ABG (2018) Dengue in Rio Grande do Sul, Brazil: 2014-2016. Rev Med Virol 28:e1960.

Grifoni A, Sidney J, Zhang Y, Scheuermann RH, Peters B and Sette A. (2020) A sequence homology and bioinformatic approach can predict candidate targets for immune responses to SARSCoV-2. Cell Host Microbe 27:671-680.

Guarner J (2020) Three emerging coronaviruses in two decades - the stidy of SARS, MERS, and now COVID-2019. Am J Clin Pathol 153:420-421.

Gubler DJ (2011) Dengue, urbanization and globalization: the unholy trinity of the $21^{\text {st }}$ century. Trop Med Health 39:3-11.

Haacker M and Birungi C (2018) Poverty as a barrier to antiretroviral therapy access for people living with HIV/AIDS in Kenya. Afr J AIDS Res 17:145-152.

Hadjadj J, Yatim N, Barnabei L, Corneau A, Boussier J, Smith N, Péré H, Charbit B, Bondet V, Chenevier-Gobeaux C, et al. (2020) Impaired type I interferon activity and inflammatory responses in severe COVID-19 patients. Science 369:718-724.

Hahn BH, Shaw GM, De Cock KM and Sharp PM (2000) AIDS as a zoonosis: scientific and public health implications. Science 287:607-614.

Hay AJ and McCauley JW (2018) The WHO global influenza surveillance and response system (GISRS) - A future perspective. Influenza Other Respi Viruses 12:551-557.

Heller L, Colosimo EA and Antunes CMF (2003) Environmental sanitation conditions and health impact: a case-control study. Rev Soc Bras Med Trop 36:41-50.

Herfst S, Böhringer M, Karo B, Lawrence P, Lewis NS, Mina MJ, Russell CJ, Steel J, de Swart RL and Menge C (2017) Drivers of airborne human-to-human pathogen transmission. Curr Opin Virol 22:22-29.

Herold T, Jurinovic V, Arnreich C, Lipworth BJ, Hellmuth JC, von Bergwelt-Baildon $\mathrm{M}$, Klein $\mathrm{M}$ and Weinberger $\mathrm{T}$ (2020) Elevated levels of IL-6 and CRP predict the need for mechanical ventilation in COVID-19. J Allergy Clin Immunol 146:128-136.e4.
Heymann DL, Liu J and Lillywhite L (2016) Partnerships, not parachutists, for Zika research. N Engl J Med 374:1504-1505.

Haidari LA, Brown ST, Ferguson M, Bancroft E, Spiker M, Wilcox A, Ambikapathi R, Sampath V, Connor DL and Lee BY (2016) The economic and operational value of using drones to transport vaccines. Vaccine 34:4062-4067.

Hodson R (2019) Vaccines. Nature 575:S43.

Hoffmann M, Kleine-Weber H, Schroeder S, Krüger N, Herrler T, Erichsen S, Schiergens TS, Herrler G, Wu NH, Nitsche A, et al. (2020) SARS-CoV-2 cell entry depends on ACE2 and TMPRSS 2 and is blocked by a clinically proven protease inhibitor. Cell 181:271-280.

Höhler T, Reuss E, Evers N, Dietrich E, Rittner C, Freitag CM, Vollmar J, Schneider PM and Fimmers R (2002) Differential genetic determination of immune responsiveness to hepatitis $B$ surface antigen and to hepatitis A virus: a vaccination study in twins. Lancet 360:991-995.

Holmes EC, Rambaut A and Andersen KG (2018) Pandemics: spend on surveillance, not prediction. Nature 558:180-182.

Hope M (2019) The Brazilian development agenda driving Amazon devastation. Lancet Planet Health 3:e409-11.

Horton R, Gibson R, Coggill P, Miretti M, Allcock RJ, Almeida J, Forbes S, Gilbert JG, Halls K, Harrow JL, et al. (2008) Variation analysis and gene annotation of eight MHC haplotypes: the MHC Haplotype Project. Immunogenetics 60:1-18.

Hotez PJ, Bethony J, Bottazzi ME, Brooker S and Buss P (2005) Hookworm: "The great infection of mankind". PLoS Med 2:e67.

Huang C, Wang Y, Li X, Ren L, Zhao J, Hu Y, Zhang L, Fan G, Xu J, $\mathrm{Gu}$ X, et al. (2020). Clinical features of patients infected with 2019 novel coronavirus in Wuhan, China. Lancet 395:497-506.

Hutton G, Haller L and Bartram J (2007) Global cost-benefit analysis of water supply and sanitation interventions. J Water Health 5:481-502.

Ibrahim MK, Zambruni M, Melby CL and Melby PC (2017) Impact of childhood malnutrition on host defense and infection. Clin Microbiol Rev 30:919-971.

Inaida S, Shobugawa Y, Matsuno S, Saito R and Suzuki H (2016) Delayed norovirus epidemic in the 2009-2010 season in Japan: potential relationship with intensive hand sanitizer use for pandemic influenza. Epidemiol Infect 144:2561-2567.

Jacobson RM and Poland GA (2004) The genetic basis for measles vaccine failure. Acta Paediatr Suppl 93:43-46.

Jacobson RM, Poland GA, Vierkant RA, Pankratz VS, Schaid DJ, Jacobsen SJ, Sauver JS and Moore SB (2003) The association of class I HLA alleles and antibody levels after a single dose of measles vaccine. Hum Immunol 64:103-109.

Jensen JT and Creinin MD (2020) Family planning, population growth, and the environment. Contraception 101:145-147.

Jia H and Wu M (2020) Sustained research fund and dedicated research center to prepare for the next pandemic. Precis Clin Med 3:94-96.

Jones KE, Patel NG, Levy MA, Storeygard A, Balk D, Gittleman JL and Daszak P (2008) Global trends in emerging infectious diseases. Nature 451:990-993.

Kalichman SC, Simbayi LC, Kagee A, Toefy Y, Jooste S, Cain D and Cherry C (2006) Associations of poverty, substance use, and HIV transmission risk behaviors in three South African communities. Soc Sci Med 62:1641-1649.

Kandeel M, Abdelrahman AHM, Oh-Hashi K, Ibrahim A, Venugopala KN, Morsy MA and Ibrahim MAA (2020) Repurposing of FDA-approved antivirals, antibiotics, anthelmintics, antioxidants, and cell protectives against SARS-CoV-2 papain-like protease. J Biomol Struct Dyn (in press). DOI: 10.1080/07391102.2020.1784291. 
Katona P and Katona-Apte J (2008) The interaction between nutrition and infection. Clin Infect Dis 46:1582-1588.

Keesing F, Belden LK, Daszak P, Dobson A, Harvell CD, Holt RD, Hudson P, Jolles A, Jones KE, Mitchell CE, et al. (2010) Impacts of biodiversity on the emergence and transmission of infectious diseases. Nature 468:647-652.

Keicho N, Itoyama S, Kashiwase K, Phi NC, Long HT, Ha LD, Ban VV, Hoa BK, Hang NT, Hijikata M, et al. (2009) Association of human leukocyte antigen class II alleles with severe acute respiratory syndrome in the Vietnamese population. Hum Immunol 70:527-531.

Khan MD, Thi Vu HH, Lai QT and Ahn JW (2019) Aggravation of human diseases and climate change nexus. Int J Environ Res Public Health 16:2799.

Kock RA, Karesh WB, Veas F, Velavan TP, Simons D, Mboera LEG, Dar O, Arruda LB and Zumla A (2020) 2019-nCoV in context: lessons learned? Lancet Planet Health 4:e87-e88.

Konda M, Dodda B, Konala VM, Naramala S and Adapa S (2020) Potential zoonotic origins of SARS-CoV-2 and insights for preventing future pandemics through One Health approach. Cureus 12:e8932.

Kouadio IK, Aljunid S, Kamigaki T, Hammad K and Oshitani H (2012) Infectious diseases following natural disasters: Prevention and control measures. Expert Rev Anti Inf Ther 10:95-104.

Kozel TR and Burnham-Marusich AR (2017) Point-of-care testing for infectious diseases: past, present, and future. J Clin Microbiol 55:2313-2320.

Kravdal Ø (1992) The emergence of a positive relation between education and third birth rates in Norway with supportive evidence from the United States. Population Stud 46:459-475.

Kruskall MS, Alper CA, Awdeh Z, Yunis EJ and Marcus-Bagley D (1992) The immune response to hepatitis B vaccine in humans: inheritance patterns in families. J Exp Med 175:495-502.

Lai S, Ruktanonchai NW, Zhou L, Prosper O, Luo W, Floyd JR, Wesolowski A, Santillana M, Zhang C, Du X, et al. (2020) Effect of non-pharmaceutical interventions to contain COVID-19 in China. Nature 585:410-413.

Lam TT, Jia N, Zhang YW, Shum MH, Jiang JF, Zhu HC, Tong YG, Shi YX, Ni XB, Liao YS, et al. (2020) Identifying SARS$\mathrm{CoV}-2$-related coronaviruses in Malayan pangolins. Nature 583: 282-285.

Larson EL and Aiello AE (2001) Hygiene and health: an epidemiologic link? Am J Infect Control 29:232-238.

Leddy AM, Turan JM, Johnson MO, Neilands TB, Kempf MC, Konkle-Parker D, Wingood G, Tien PC, Wilson TE, Logie $\mathrm{CH}$, et al. (2019) Poverty stigma is associated with suboptimal HIV care and treatment outcomes among women living with HIV in the United States. AIDS 33:1379-1384.

Lee JS and Shin EC (2020) The type I interferon response in COVID-19: implications for treatment. Nat Rev Immunol 20:585-586.

Lee JS, Park S, Jeong HW, Ahn JY, Choi SJ, Lee H, Choi B, Nam SK, Sa M, Kwon JS, et al. (2020) Immunophenotyping of COVID-19 and influenza highlights the role of type I interferons in development of severe COVID-19. Sci Immunol 5:eabd1554.

Lemonick DM (2011) Epidemics after natural disasters. Am J Clin Med 8:144-152.

Li J, Li JJ, Xie X, Cai X, Huang J, Tian X and Zhu H (2020) Game consumption and the 2019 novel coronavirus. Lancet Infect Dis 20:275-276.

Li X, Giorgi EE, Marichannegowda MH, Foley B, Xiao C, Kong XP, Chen Y, Gnanakaran S, Korber B and Gao F (2020) Emergence of SARS-CoV-2 through recombination and strong purifying selection. Sci Adv 6:eabb9153
Lin M, Tseng HK, Trejaut JA, Lee HL, Loo JH, Chu CC, Chen PJ, Su YW, Lim KH, Tsai ZU, et al. (2003) Association of HLA class I with severe acute respiratory syndrome coronavirus infection. BMC Med Genet 4:9.

Lönnroth K, Jaramillo E, Williams BG, Dye C and Raviglione M (2009) Drivers of tuberculosis epidemics: the role of risk factors and social determinants. Soc Sci Med 68:2240-2246.

Lönnroth K, Castro KG, Chakaya JM, Chauhan LS, Floyd K, Glaziou P and Raviglione MC (2010) Tuberculosis control and elimination 2010-50: cure, care, and social development. Lancet 375:1814-1829.

Lot F, Semaille C, Cazein F, Barin F, Pinget R, Pillonel J and Desenclos JC (2004) Preliminary results from the new HIV surveillance system in France. Euro Surveill 9: 34-37.

Lucas C, Wong P, Klein J, Castro TBR, Silva J, Sundaram M, Ellingson MK, Mao T, Oh JE, Israelow B, et al. (2020) Longitudinal analyses reveal immunological misfiring in severe COVID-19. Nature 584:463-469.

Lygizos M, Shenoi SV, Brooks RP, Bhushan A, Brust JC, Zelterman D, Deng Y, Northrup V, Moll AP and Friedland GH (2013) Natural ventilation reduces high $\mathrm{TB}$ transmission risk in traditional homes in rural KwaZulu-Natal, South Africa. BMC Infect Dis 13:300.

Ma W, Kahn RE and Richt JA (2009) The pig as a mixing vessel for influenza viruses: Human and veterinary implications. J Mol Genet Med 3:158-166.

Mabey D, Peeling RW, Ustianowski A and Perkins MD (2004) Diagnostics for the developing world. Nat Rev Microbiol 2:231-240.

Magierowska M, Theodorou I, Debré P, Sanson F, Autran B, Rivière Y, Charron D, French ALT and IMMUNOCO Study Groups and Costagliola D (1999) Combined genotypes of CCR5, CCR2, SDF1, and HLA genes can predict the long-term nonprogressor status in human immunodeficiency virus-1infected individuals. Blood 93:936-941.

Mahrous H, Redi N, Nguyen TMN, Al Awaidy S, Mostafavi E and Samhouri D (2020) One Health operational framework for action for the Eastern Mediterranean Region, focusing on zoonotic diseases. East Mediterr Health J 26:720-725.

Mallal S, Nolan D, Witt C, Masel G, Martin AM, Moore C, Sayer D, Castley A, Mamotte C, Maxwell D, et al. (2002) Association between presence of HLA-B*5701, HLA-DR7, and HLA-DQ3 and hypersensitivity to HIV-1 reverse-transcriptase inhibitor abacavir. Lancet 359:727-732

Mallal S, Phillips E, Carosi G, Molina JM, Workman C, Tomazic J, Jägel-Guedes E, Rugina S, Kozyrev O, Cid JF, et al. (2008) HLA-B*5701 screening for hypersensitivity to abacavir. N Engl J Med 358:568-579.

Mallhi TH, Khan YH, Alotaibi NH, Alzarea AI, Alanazi AS, Qasim S, Iqbal MS and Tanveer N (2020) Drug repurposing for COVID-19: a potential threat of self-medication and controlling measures. Postgrad Med J. In press. doi: 10.1136/ postgradmedj-2020-138447

Mara D, Lane J, Scott B and Trouba D (2010) Sanitation and health. PLoS Med 7:e1000363.

Marston HD, Dixon DM, Knisely JM, Palmore TN and Fauci AS (2016) Antimicrobial Resistance. JAMA 316:1193-1204.

Martin MP, Gao X, Lee JH, Nelson GW, Detels R, Goedert JJ, Buchbinder S, Hoots K, Vlahov D, Trowsdale J, et al. (2002) Epistatic interaction between KIR3DS1 and HLA-B delays the progression to AIDS. Nat Genet 31:429-434.

Martinez MA (2020) Clinical trials of repurposed antivirals for SARSCoV-2. Antimicrob Agents Chemother 64:e01101-e01120.

Martins-Melo FR, Carneiro M, Ramos AN Jr, Heukelbach J, Ribeiro ALP and Werneck GL (2018) The burden of Neglected Tropical Diseases in Brazil, 1990-2016: A subnational analysis from 
the Global Burden of Disease Study 2016. PLoS Negl Trop Dis 12:e0006559.

Mathews TJ and Ventura SJ (1997) Birth and fertility rates by educational attainment: United States, 1994. Mon Vital Stat Rep 45:1-20.

Matricardi EAT, Skole DL, Costa OB, Pedlowski MA, Samek JH and Miguel EP (2020) Long-term forest degradation surpasses deforestation in the Brazilian Amazon. Science 369:1378-1382.

McCormack S, Dunn DT, Desai M, Dolling DI, Gafos M, Gilson R, Sullivan AK, Clarke A, Reeves I, Schembri G, et al. (2016) Pre-exposure prophylaxis to prevent the acquisition of HIV-1 infection (PROUD): effectiveness results from the pilot phase of a pragmatic open-label randomised trial. Lancet 387:53-60.

McKeown RE (2009) The epidemiologic transition: Changing patterns of mortality and population dynamics. Am J Lifestyle Med 3:19S-26S.

McLeod A, Weir A, Aitken C, Gunson R, Templeton K, Molyneaux $\mathrm{P}$, McIntyre P, McDonald S, Goldberg D and Hutchinson S (2014) Rise in testing and diagnosis associated with Scotland's Action Plan on Hepatitis C and introduction of dried blood spot testing. J Epidemiol Community Health 68:1182-1188.

Mendonça LET, Vasconcellos A, Souto CM, Oliveira TPR and Alves ARN (2016) Bushmeat consumption and its implications for wildlife conservation in the semi-arid region of Brazil. Reg Environ Change 16:1649-1657.

Mendoza H, Rubio AV, García-Peña GE, Suzán G and Simonetti JA (2020) Does land-use change increase the abundance of zoonotic reservoirs? Rodents say yes. Eur J Wildlife Res 66:6.

Metsky HC, Matranga CB, Wohl S, Schaffner SF, Freije CA, Winnicki SM, West K, Qu J, Baniecki ML, Gladden-Young A, et al. (2017) Zika virus evolution and spread in the Americas. Nature 546:411-415.

Meyer H, Ehmann R and Smith GL (2020) Smallpox in the posteradication era. Viruses. 12:138.

Mills JN (2006) Biodiversity loss and emerging infectious disease: An example from the rodent-borne hemorrhagic fevers. Biodiversity 7:9-17.

Migueles SA, Sabbaghian MS, Shupert WL, Bettinotti MP, Marincola FM, Martino L, Hallahan CW, Selig SM, Schwartz D, Sullivan $\mathrm{J}$, et al. (2000) HLA B*5701 is highly associated with restriction of virus replication in a subgroup of HIV-infected long term nonprogressors. Proc Natl Acad Sci U S A 97:2709-2714.

Moreira VLC, Giese EG, da Silva DCB, Melo FTV, Furtado AP, Maldonado Jr A and dos Santos JN (2013) Calodium hepaticum (Nematoda: Capillariidae) in synanthropic rodents (Rattus norvegicus and Rattus rattus) in Eastern Amazonia. Rev Bras Parasitol Vet 22:265-269.

Morens DM and Fauci AS (2020) Emerging pandemic diseases: How we got to COVID-19. Cell 182:1077-1092.

Morgan DJ, Okeke IN, Laxminarayan R, Perencevich EN and Weisenberg S (2011) Non-prescription antimicrobial use worldwide: a systematic review. Lancet Infect Dis 11:692-701.

Morse SS (1995) Factors in the emergence of infectious diseases. Emerg Infect Dis 1:7-15.

Morse SS, Mazet JA, Woolhouse M, Parrish CR, Carroll D, Karesh WB, Zambrana-Torrelio C, Lipkin WI and Daszak P (2012) Prediction and prevention of the next pandemic zoonosis. Lancet 380:1956-1965.

Mozzi A, Pontremoli C and Sironi M (2018) Genetic susceptibility to infectious diseases: Current status and future perspectives from genome-wide approaches. Infect Genet Evol 66:286-307.

Mullinax M, Mathur S and Santelli J (2017) Adolescent sexual health and sexuality education. In: Cherry A, Baltag V and Dillon M (eds) International Handbook on Adolescent Health and Development. Springer International Publishing, Cham, Switzerland, pp 143-167.
Murray MH, Fidino M, Fyffe R, Byers KA, Pettengill JB, Sondgeroth KS, Killion H, Magle SB, Rios MJ, Ortinau N, et al. (2020) City sanitation and socioeconomics predict rat zoonotic infection across diverse neighbourhoods. Zoonoses Public Health 67:673-683

Nabel GJ (2013) Designing tomorrow's vaccines. N Engl J Med 368:551-560.

Nagot N, Kankasa C, Tumwine JK, Meda N, Hofmeyr GJ, Vallo R, Mwiya M, Kwagala M, Traore H, Sunday A, et al. (2016) Extended pre-exposure prophylaxis with lopinavir-ritonavir versus lamivudine to prevent HIV-1 transmission through breastfeeding up to 50 weeks in infants in Africa (ANRS 12174): a randomised controlled trial. Lancet 387:566-573.

Nava A, Shimabukuro JS, Chmura AA and Luz SLB (2017) The impact of global environmental changes on infectious disease emergence with a focus on risks for Brazil. ILAR J 58:393-400.

Neiderud CJ (2015) How urbanization affects the epidemiology of emerging infectious diseases. Infect Ecol Epidemiol 5:27060.

Newport MJ, Goetghebuer T, Weiss HA, Whittle H, Siegrist CA, Marchant A, MRC Gambia Twin Study Group (2004) Genetic regulation of immune responses to vaccines in early life. Genes Immun 5:122-129.

Nguyen A, David JK, Maden SK, Wood MA, Weeder BR, Nellore A and Thompson RF (2020) Human leukocyte antigen susceptibility map for severe acute respiratory syndrome coronavirus 2. J Virol 94:e0510-20.

Nogueira EM, Yanai AM, Vasconcelos SS, Graça PMLA and Fearnside PM (2018) Brazil's Amazonian protected areas as a bulwark against regional climate change. Reg Environ Change 18:573-579.

Oppenheim B, Gallivan M, Madhav NK, Brown N, Serhiyenko V, Wolfe ND and Ayscue P (2018) Assessing global preparedness for the next pandemic: development and application of an Epidemic Preparedness Index. BMJ Glob Health 4:e001157.

Ordaz-Németh I, Arandjelovic M, Boesch L, Gatiso T, Grimes T, Kuehl HS, Lormie M, Stephens C, Tweh C and Junker J (2017) The socio-economic drivers of bushmeat consumption during the West African Ebola crisis. PLoS Negl Trop Dis 11:e005450.

Orenstein WA, Seib K, Graham-Rowe D and Berkley S (2014) Contemporary vaccine challenges: improving global health one shot at a time. Sci Transl Med 6:253ps11.

Orenstein WA and Ahmed R (2017) Simply put: Vaccination saves lives. Proc Natl Acad Sci U S A 114:4031-4033.

Ortiz-Fernández L and Sawalha AH (2020) Genetic variability in the expression of the SARS-CoV-2 host cell entry factors across populations. bioRxiv:2020.04.06.027698.

Pan A, Liu L, Wang C, Guo H, Hao X, Wang Q, Huang J, He N, Yu H, Lin X, et al. (2020) Association of public health interventions with the epidemiology of the COVID-19 outbreak in Wuhan, China. JAMA 323:1915-1923.

Perlman S (2020) COVID-19 poses a riddle for the immune system. Nature 584:345-346.

Piddock LJV (2012) The crisis of no new antibiotics-what is the way forward? Lancet Infect Dis 12:249-253.

Pigott DM, Howes RE, Wiebe A, Battle KE, Golding N, Gething PW, Dowell SF, Farag TH, Garcia AJ, Kimball AM, et al. (2015) Prioritising infectious disease mapping. PLoS Negl Trop Dis 9:e0003756.

Pinto BGG, Oliveira AER, Singh Y, Jimenez L, Gonçalves ANA, Ogava RLT, Creighton R, Peron JPS and Nakaya HI (2020) ACE2 expression is increased in the lungs of patients with comorbidities associated with severe COVID-19. J Infect Dis J Infect Dis 222:556-563. 
Piot P, Larson HJ, O'Brien KL, N'kengasong J, Ng E, Sow S and Kampmann B (2019) Immunization: vital progress, unfinished agenda. Nature 575:119-129.

Plowright RK, Parrish CR, McCallum H, Hudson PJ, Ko AI, Graham AL and Lloyd-Smith JO (2017) Pathways to zoonotic spillover. Nat Rev Microbiol 15:502-510.

Prüss-Ustün A, Wolf J, Corvalán C, Neville T, Bos R and Neira M (2017) Diseases due to unhealthy environments: an updated estimate of the global burden of disease attributable to environmental determinants of health. J Public Health (Oxf) 39:464-475.

Quinn SC and Kumar S (2014) Health inequalities and infectious disease epidemics: a challenge for global health security. Biosecur Bioterror 12:263-273.

Rabinowitz P and Conti L (2013) One Health and emerging infectious diseases: clinical perspectives. Curr Top Microbiol Immunol 365:17-29.

Rahelinirina S, Bourhy P, Andriamiaramanana F, Garin B and Rajerison M (2019) High prevalence of Leptospira spp. in rodents in an urban setting in Madagascar. Am J Trop Med Hyg 100:1079-1081.

Rhodes CJ (2012) Feeding and healing the world: through regenerative agriculture and permaculture. Sci Prog 95:345-446.

Ripple WJ, Abernethy K, Betts MG, Chapron G, Dirzo R, Galetti M, Levi T, Lindsey PA, Macdonald DW, Machovina B, et al. (2016) Bushmeat hunting and extinction risk to the world's mammals. R Soc Open Sci 3:160498.

Ross AGP, Crowe SM and Tyndall MW (2015) Planning for the next global pandemic. Int J Infect Dis 38:89-94.

Rosser JC Jr, Vignesh V, Terwilliger BA and Parker BC (2018) Surgical and medical applications of drones: A comprehensive review. JSLS 22:e2018.00018.

Rubrichi S, Smoreda Z and Musolesi M (2018) A comparison of spatial-based targeted disease mitigation strategies using mobile phone data. EPJ Data Sci 7:17.

Ruwende C, Khoo SC, Snow RW, Yates SNR, Kwiatkowski D, Gupta S, Warn P, Allsopp CEM, Gilbert SC, Peschu N, et al. (1995) Natural selection of hemi- and heterozygotes for G6PD deficiency in Africa by resistance to severe malaria. Nature 376:246-249.

Salata C, Calistri A, Parolin C and Palù G (2019) Coronaviruses: a paradigm of new emerging zoonotic diseases. Pathog Dis 77:ftaa006.

Sayer J and Cassman KG (2013) Agricultural innovation to protect the environment. Proc Natl Acad Sci U S A 110:8345-8348.

Schaible UE and Kaufmann SHE (2007) Malnutrition and infection: complex mechanisms and global impacts. PLoS Med 4:e115.

Schiavo R, Leung MM and Brown M (2014) Communicating risk and promoting disease mitigation measures in epidemics and emerging disease settings. Pathog Glob Health 108:76-94.

Schlesinger WH (2010) Translational ecology. Science 329:609.

Schmidhuber J and Tubiello FN (2007) Global food security under climate change. Proc Natl Acad Sci USA 104:19703-19708.

Senanayake SL (2020) Drug repurposing strategies for COVID-19. Future Drug Discov 2:FDD40.

Shi Y, Wang Y, Shao C, Huang J, Gan J, Huang X, Bucci E, Piacentini M, Ippolito G and Melino G (2020) COVID-19 infection: the perspectives on immune responses. Cell Death Differ 27:1451-1454

Shokoohi M, Karamouzian M, Khajekazemi R, Osooli M, Sharifi H, Haghdoost AA, Kamali K and Mirzazadeh A (2016) Correlates of HIV testing among female sex workers in Iran: findings of a national bio-behavioural surveillance survey. PLoS One 11:e0147587.

Shukla J, Nobre C and Sellers P (1990) Amazon deforestation and climate change. Science 247:1322-1325.
Smith R (2000) Vaccines and medicines for the world's poorest. Public-private partnerships seem to be essential. BMJ 320:952953.

Sokolow SH, Nova N, Pepin KM, Peel AJ, Pulliam JRC, Manlove $\mathrm{K}$, Cross PC, Becker DJ, Plowright RK, McCallum H, et al. (2019) Ecological interventions to prevent and manage zoonotic pathogen spillover. Philos Trans R Soc Lond B Biol Sci 374:20180342.

Stahl JP, Cohen R, Denis F, Gaudelus J, Martinot A, Lery T and Lepetit H (2016) The impact of the web and social networks on vaccination. New challenges and opportunities offered to fight against vaccine hesitancy. Med Mal Infect 46:117-122.

Stephens HAF, Klaythong R, Sirikong M, Vaughn DW, Green S, Kalayanarooj S, Endy TP, Libraty DH, Nisalak A, Innis BL, et al. (2002) HLA-A and -B allele associations with secondary dengue virus infections correlate with disease severity and the infecting viral serotype in ethnic Thais. Tissue Antigens 60:309-318.

Stringer S, Wray NR, Kahn RS and Derks EM (2011) Underestimated effect sizes in GWAS: fundamental limitations of single SNP analysis for dichotomous phenotypes. PLoS One 6:e27964.

Succi RCM (2018) Vaccine refusal - what we need to know. J Pediatr (Rio J) 94:574-581.

Taylor LH, Latham SM and Woolhouse MEJ (2001) Risk factors for human disease emergence. Philos Trans R Soc Lond B Biol Sci 356:983-989.

Tenover FC (2006) Mechanisms of antimicrobial resistance in bacteria. Am J Med 119:S3-S10.

Tian H, Hu S, Cazelles B, Chowell G, Gao L, Laine M, Li Y, Yang H, Li Y, Yang Q, et al. (2018) Urbanization prolongs hantavirus epidemics in cities. Proc Natl Acad Sci U S A 115:4707-4712.

Tomiyama H, Miwa K, Shiga H, Moore YI, Oka S, Iwamoto A, Kaneko Y and Takiguchi M (1997) Evidence of presentation of multiple HIV-1 cytotoxic T lymphocyte epitopes by HLA-B*3501 molecules that are associated with the accelerated progression of AIDS. J Immunol 158:5026-5034.

Tuaillon E, Kania D, Pisoni A, Bollore K, Taieb F, Ontsira Ngoyi EN, Schaub R, Plantier JC, Makinson A and Van de Perre P (2020) Dried blood spot tests for the diagnosis and therapeutic monitoring of HIV and viral hepatitis B and C. Front Microbiol 11:373.

Valverde-Villegas JM, Dos Santos BP, de Medeiros RM, Mattevi VS, Lazzaretti RK, Sprinz E, Kuhmmer R and Chies JAB (2017a) Endosomal toll-like receptor gene polymorphisms and susceptibility to HIV and HCV co-infection - Differential influence in individuals with distinct ethnic background. Hum Immunol 78:221-226.

Valverde-Villegas JM, de Medeiros RM, de Andrade KP, Jacovas VC, dos Santos BR, de Matos Almeida SE, Simon D and Chies JAB (2017b) Novel genetic associations and gene-gene interactions of chemokine receptor and chemokine genetic polymorphisms in HIV/AIDS. AIDS 31:1235-1243.

Van Minh H and Hung NV (2011) Economic aspects of sanitation in developing countries. Environ Health Insights 5:63-70.

Vörösmarty CJ, Green P, Salisbury J and Lammers RB (2000) Global water resources: vulnerability from climate change and population growth. Science 289:284-288.

Vouking MZ, Mengue CMA, Yauba S, Edengue JM, Dicko M, Dicko HM and Wiysonge CS (2019) Interventions to increase the distribution of vaccines in Sub-Saharan Africa: a scoping review. Pan Afr Med J 32:14.

Walensky RP, Freedberg KA, Weinstein MC and Paltiel AD (2007) Cost-effectiveness of HIV testing and treatment in the United States. Clin Infect Dis 45:S248-S254.

Walker CF and Black RE (2004) Zinc and the risk for infectious disease. Annu Rev Nutr 24:255-275. 
Wang D, Hu B, Hu C, Zhu F, Liu X, Zhang J, Wang B, Xiang H, Cheng Z, Xiong Y, et al. (2020) Clinical characteristics of 138 hospitalized patients with 2019 novel coronavirus-infected pneumonia in Wuhan, China. JAMA 323:1061-1069.

Wang SF, Chen KH, Chen M, Li WY, Chen YJ, Tsao CH, Yen MY, Huang JC and Chen YMA (2011) Human-leukocyte antigen class I Cw 1502 and class II DR 0301 genotypes are associated with resistance to severe acute respiratory syndrome (SARS) infection. Viral Immunol 24:421-426.

Watson JEM, Keith DA, Strassburg BBN, Venter O, Williams B and Nicholson E (2020) Set a global target for ecosystems. Nature 578:360-362.

Watson JT, Gayer M and Connolly MA (2007) Epidemics after natural disasters. Emerg Infect Dis 13:1-5.

Wernli D, Jørgensen PS, Parmley EJ, Troell M, Majowicz S, Harbarth S, Léger A, Lambraki I, Graells T, Henriksson PJG, et al. (2020) Evidence for action: a One Health learning platform on interventions to tackle antimicrobial resistance. Lancet Infect Dis 20:e307-e311

West TAP, Börner J and Fearnside PM (2019) Climatic benefits from the 2006-2017 avoided deforestation in Amazonian Brazil. Front For Glob Change 2:52.

Whitworth J (2020) COVID-19: a fast evolving pandemic. Trans R Soc Trop Med Hyg 114:241-248.

WHO - World Health Organization (2017a) Guidlines on hepatitis $\mathrm{B}$ and $\mathrm{C}$ testing. Annexe 4.2. Who to test HCV. World Health Organization, Geneva, pp 28-51.

WHO - World Health Organization (2017b) Global vector control response 2017-2030. World Health Organization, Geneva, p. 53.

Wilson AL, Courtenay O, Kelly-Hope LA, Scott TW, Takken W, Torr SJ and Lindsay SW (2020) The importance of vector control for the control and elimination of vector-borne diseases. PLoS Negl Trop Dis 14:e0007831.

WIPO - World Intellectual Property Organization (2019) WIPO Re:Search Advancing Product Development for Neglected Infectious Diseases through Global Public-Private Partnerships. BIO Ventures for Global Health, Seattle. p. 15.

Wolfe ND, Daszak P, Kilpatrick AM and Burke DS (2005) Bushmeat hunting, deforestation, and prediction of zoonoses emergence. Emerg Infect Dis 11:1822-1827.

Wolfe ND, Dunavan CP and Diamond J (2007) Origins of major human infectious diseases. Nature 447:279-283.

Woolhouse MEJ and Gowtage-Sequeria S (2005) Host range and emerging and reemerging pathogens. Emerg Infect Dis 11:1842-1847.

Wu F, Zhao S, Yu B, Chen YM, Wang W, Song ZG, Hu Y, Tao ZW, Tian JH, Pei YY, et al. (2020) A new coronavirus associated with human respiratory disease in China. Nature 579:265-269.

Wu X, Lu Y, Zhou S, Chen L and Xu B (2016) Impact of climate change on human infectious diseases: Empirical evidence and human adaptation. Environ Int 86:14-23.

Wu Y, Feng Z, Li P and Yu Q (2020) Relationship between ABO blood group distribution and clinical characteristics in patients with COVID-19. Clin Chim Acta 509:220-223.

Xiao Y and Torok ME (2020) Taking the right measures to control COVID-19. Lancet Infect Dis 20:523-524.

$\mathrm{Xu}$ Y (2020) Unveiling the origin and transmission of 2019-nCoV. Trends Microbiol 28:239-240.

Yang G, Kim D, Pham A and Paul CJ (2018) A meta-regression analysis of the effectiveness of mosquito nets for malaria control: the value of long-lasting insecticide nets. Int $\mathrm{J}$ Environm Res Public Health 15:546.

Yang P and Wang X (2020) COVID-19: a new challenge for human beings. Cell Mol Immunol 17:555-557.
Yamey G, Schäferhoff M, Aars OK, Bloom B, Carroll D, Chawla M, Dzau V, Echalar R, Gill IS, Godal T, et al. (2017) Financing of international collective action for epidemic and pandemic preparedness. Lancet Glob Health 5:e742-e744.

Yozwiak NL, Happi CT, Grant DS, Schieffelin JS, Garry RF, Sabeti PC and Andersen KG (2016) Roots, not parachutes: research collaborations combat outbreaks. Cell 166: 5-8.

Zhang YZ and Holmes EC (2020) A genomic perspective on the origin and emergence of SARS-CoV-2. Cell 181:223-227.

Zhang T, Wu Q and Zhang Z (2020) Probable pangolin origin of SARS-CoV-1 2 associated with the COVID-19 outbreak. Curr Biol 30:1346-1351.

Zhao J, Yang Y, Huang H, Li D, Gu D, Lu X, Zhang Z, Liu L, Liu T, Liu $\mathrm{Y}$, et al. (2020) Relationship between the ABO blood group and the COVID-19 susceptibility. medRxiv:2020.03.11.20031096.

Zhou NN, Senne DA, Landgraf JS, Swenson SL, Erickson G, Rossow K, Liu L, Yoon Kj, Krauss S and Webster RG (1999) Genetic reassortment of avian, swine, and human influenza A viruses in American pigs. J Virol 73:8851-8856.

Zhou F, Yu T, Du R, Fan G, Liu Y, Liu Z, Xiang J, Wang Y, Song $\mathrm{B}, \mathrm{Gu} \mathrm{X}$, et al. (2020) Clinical course and risk factors for mortality of adult inpatients with COVID-19 in Wuhan, China: a retrospective cohort study. Lancet 395:1054-1062.

Zhou P, Yang XL, Wang XG, Hu B, Zhang L, Zhang W, Si HR, Zhu Y, Li B, Huang CL, et al. (2020) A pneumonia outbreak associated with a new coronavirus of probable bat origin. Nature 579:270-273.

Zhu N, Zhang D, Wang W, Li X, Yang B, Song J, Zhao X, Huang B, Shi W, Lu R, et al. (2020) A novel coronavirus from patients with pneumonia in China, 2019. N Engl J Med 382:727-733.

\section{Internet Resources}

Brasil - Ministério da Saúde, Departamento de Doenças de Condições Crônicas e Infecções Sexualmente Transmissíveis (2020) Testagem, http://www.aids.gov.br/pt-br/publico-geral/ prevencao-combinada/testagem (accessed 23 April 2020).

CDC - Center for Disease Control and Prevention, National Center for Emerging and Zoonotic Infectious Diseases (NCEZID), Division of Foodborne, Waterborne, and Environmental Diseases (DFWED) (2014) Cholera in Haiti, https://www. cdc.gov/cholera/haiti/index.html (accessed 21 April 2020).

CDC - Centers for Disease Control and Prevention, National Center for Emerging and Zoonotic Infectious Diseases (NCEZID), Division of Foodborne, Waterborne, and Environmental Diseases at CDC (2017) Global Diarrhea Burden - Diarrhea: Common Illness, Global Killer, https://www.cdc.gov/ healthywater/global/diarrhea-burden.html\#pathways (accessed 20 April 2020).

CDC - Center for Disease Control and Prevention, Division of HIV/AIDS Prevention, National Center for HIV/AIDS, Viral Hepatitis, STD, and TB Prevention (2019) PrEP, https://www. cdc.gov/hiv/basics/prep.html (accessed 20 April 2020).

ILOAIDS - ILO Programme on HIV/AIDS and the World of Work (2005) HIV/AIDS and poverty: the critical connection, https:// www.ilo.org/wcmsp5/groups/public/---ed_protect/---protrav/--ilo_aids/documents/publication/wcms_120468.pdf (accessed 13 March 2020).

INPE - Instituto Nacional de Pesquisas Espaciais (National Institute for Space Research, Brazil) (2020) TerraBrasilia, PRODES (Desmatamento). Taxas de desmatamento - Amazônia Legal - Estados. http://terrabrasilis.dpi.inpe.br/app/dashboard/ deforestation/biomes/legal_amazon/rates (accessed $28 \mathrm{March}$ 2020). 
Institute of Medicine - Institute of Medicine (US) Committee for the Study of the Future of Public Health. The Future of Public Health. National Academies Press (US), Washington, D.C. (1988) 3, A History of the Public Health System, https:// www.ncbi.nlm.nih.gov/books/nbk218224/ (accessed 21 March 2020).

Johns Hopkins University (2020) COVID-19 Dashboard by the Center for Systems Science and Engineering (CSSE) at Johns Hopkins University, https://coronavirus.jhu.edu/map.html (accessed 16 October 2020).

S2iD - Sistema Integrado de Informações sobre Desastres (2013) Relatório Gerencial, https://s2id.mi.gov.br/paginas/relatorios/ (accessed 21 April 2020).

WHO - World Health Organization (2019) Global Influenza Strategy 2019-2030.World Health Organization, Geneva. Cataloguingin-Publication (CIP) data, http://apps.who.int/iris (accessed 20 April 2020).

WHO - World Health Organization (2020a) Vector-borne diseases, https://www.who.int/news-room/fact-sheets/detail/vectorborne-diseases (accessed 13 March 2020).

WHO - World Health Organization (2020b) Mosquito-borne diseases: Mosquitoes cause millions of deaths every year, https://www. who.int/neglected_diseases/vector_ecology/mosquito-bornediseases/en/ (accessed 13 March 2020).
WHO - World Health Organization (2020c) WHO save lives: clean your hands in the context of COVID-19, https://www.who. int/infection-prevention/campaigns/clean-hands/who hhcommunity-campaign_finalv3.pdf?ua $=1$ (accessed 16 October 2020).

WHO - World Health Organization (2020d) WHO Director-General's opening remarks at the media briefing on COVID-19, 11 March 2020, https://www.who.int/dg/speeches/detail/who-directorgeneral-s-opening-remarks-at-the-media-briefing-on-covid19---11-march-2020 (accessed 20 April 2020).

WWF - World Wide Fund for Nature, Brasil (2019) Câmara pode liberar caça de animais silvestres no Brasil, https:// www.wwf.org.br/informacoes/noticias_meio_ambiente_e_ natureza/?72624/camara-pode-liberar-a-caca-de-animaissilvestres-no-brasil (accessed 13 March 2020).

Associate Editor: Diogo Meyer

License information: This is an open-access article distributed under the terms of the Creative Commons Attribution License (type CC-BY), which permits unrestricted use, distribution and reproduction in any medium, provided the original article is properly cited. 